International Journal of Science and Education, 4(3), 157-178

Uluslararası Bilim ve Eğitim Dergisi, 4(3), 157-178

DOI: 10.47477/ubed.917732

Makale Türü: Araştırma Makalesi

Başvuru Tarihi: 16.04 .2021

Yayına Kabul Tarihi: 29.09.2021

\title{
Türkiye'de Matematik Eğitimi Alanında Üstün Zekalılar ve Özel Yetenekliler Konusunda Yürütülmüsş Tezlerin Tematik ve Yöntemsel Eğilimleri
}

\author{
Deniz KAYA ${ }^{1 *}$
}

Öz

Bu çalışmanın amacı, Türkiye'de matematik eğitimi alanında üstün zekalılar ve özel yetenekliler konusunda yürütülmüş lisansüstü tezlerin tematik ve yöntemsel eğilimlerinin neler olduğunu belirlemektir. Bu doğrultuda, Yükseköğretim Kurulu Ulusal Tez Merkezi veri tabanından Kasım 2020 tarihine kadar yayımlanmış ve erişim izni olan lisansüstü tezler incelenmiştir. Dokümanların incelenmesinde, betimsel içerik analizinden yararlanılmıştır. Veri tabanı taramasında toplam 53 lisansüstü tez çalışmasına ulaşılmıştır. Tezler tema, çalışma konusu, yayın yılı, türü, yaklaşımı, yaklaşım açıklaması, örneklem düzeyi, veri toplama aracı ve analiz açıklaması başlıkları altında analiz edilmiştir. Analiz sonucunda, tezlerin çoğunlukla üstün zekalı ve özel yetenekli öğrencilerin bilişsel özelliklerini konu edindiği belirlenmiştir. Ayrıca cebir öğrenme alanına tezlerde daha fazla yer verilmiştir. Nicel yaklaşımlar daha çok tercih edilirken ilişkisel tarama ile deneysel araştırmalar sıklıkla kullanılmıştır. Veri toplama aracı olarak yarı yapılandırılmış görüşme formları, ölçekler ile testler, analizlerde ise nicel kestirimsel analizler daha çok kullanılmıştır. Örneklem düzeyi olarak en fazla ortaokul öğrencileri ile çalışılmıştır.

Anahtar Kelimeler: Matematik eğitimi, tematik, üstün zekalı ve özel yetenekli öğrenciler, yöntemsel eğilim

\section{A Thematic and Methodological Trends of Postgraduate Theses Conducted on Gifted and Talented Students in the Field of Mathematics Education in Turkey}

\begin{abstract}
This study aims to determine the thematic and methodological trends of postgraduate theses conducted on gifted and talented students in the field of mathematics education in Turkey. Accordingly, postgraduate theses published from the National Thesis Center database of the Higher Education Council until November 2020 and have access permission were examined. Descriptive content analysis was used in the examination of the documents. A total of 53 postgraduate theses studies were reached in the database scan. These were analyzed under the headings of theme, study subject, publication year, type, approach, approach explanation, sample level, data collection tool, and analysis explanation. As a result of the analysis, it was determined that these mostly focus on the cognitive characteristics of gifted and talented students. Also, the field of algebra learning has been given included more in theses. While quantitative approaches are preferred more, relational scanning and experimental research have been used frequently. Semi-structured interview forms, scales, and tests were used as data collection tools, and quantitative predictive analyzes were used more in analyzes. As the sampling level, mostly middle school students were studied.
\end{abstract}

Key Words: Gifted and talented students, mathematics education, thematic, methodological trends

1*Corresponding Author: Dr., Milli Eğitim Bakanlığı, İzmir, Türkiye, denizkaya50@yahoo.com, ORCID: 0000000278041772 


\section{Giriş}

21. yüzyıl bilgi çağında bireysel farklılıkların öneminin her geçen gün daha iyi anlaşılmasıyla birlikte öğretim programlarının bu farklılıkları merkeze alan bir anlayışa doğru evrildiği dikkat çekmektedir. Özellikle günümüz bilgi toplumlarında süreklilik arz eden ihtiyaçlar ve gereksinimlere bağlı olarak bireylerin kendi potansiyellerini ve yeteneklerini keşfetmesine olanak tanıyan öğretim programlarının geliştirilmesi zorunluluğu bu evrilmeyi daha da hızlandırmıştır (Çalık \& Sezgin, 2005; Özkan, 2009). Toplum 5.0 (süper akıllı toplum) anlayışının gelişmesiyle birlikte teknolojik gelişmelerin topluma entegre edilmesinin amaçlanması öğretim programlarından beklentileri de farklı bir boyuta taşımıştır (Saracel \& Aksoy, 2020). Nitekim çok sayıdaki ulusun eğitim politikalarında bu radikal beklentilerin izlerine rastlamak mümkündür (CCSSI, 2010; European Commission/EACEA/Eurydice, 2018; MEB, 2017; NCTM, 2014; NRC, 2011; OECD, 2018). Bu durumun haklı gerçekleri arasında bireysel niteliklere duyulan gereksinimin daha fazla ön plana çıkmasının yanı sıra bireylerin sahip olduğu fizyolojik ve psikolojik özelliklerin farklılık göstermesi de yer almaktadır. Bireyleri birbirinden farklı kılan bu özelliklerin başında ise zekâ ve yetenek kavramları yer almaktadır. Zekâ bireylerin çevreye uyumunu sağlamak için ihtiyaç duyduğu zihinsel yeteneklerin toplamı ya da belli bir amaca yönelik ilerleyebilme kapasite olarak tanımlanmaktadır (Garlick, 2002; Sternberg, 1997). Zekâ kavramının tanımına yönelik ilgili alanyazında çok sayıda ve farklı türde tanıma rastlamak mümkün olsa da genel manada; soyut düşünme, karar verme, problem çözme, muhakeme etme, akıl yürütme gibi öğrenme yeteneği bir başka ifade ile çevrenin beklentilerini etkili bir şekilde karşılamak için adaptasyon sağlama olarak nitelendirilmektedir (Flynn, 2007; Sternberg, 1997). Yetenek kavramı ise beceriler topluluğu şeklinde değerlendirilmektedir. Yetenek; özel bir alanda gelişmiş olma özelliğine doğuştan sahip olma durumu ve bu yeteneğin ilerletilmesiyle başarıya ulaşma yolu olarak tanımlanmaktadır (Gagne, 2004). Diğer yandan alanyazında üstün zekâ ve özel yetenek kavramları genellikle birlikte değerlendirilmekte ve tanımlarındaki farklıkların nedenleri olarak zekânın karmaşık yapısı ile bireysel ve disiplinlerarası farkl1lıklar gösterilmektedir (Bapoğlu-Dümenci, 2018; Flynn, 2007; Goleman, 2005; Sak, 2011; Sousa, 2007). Örneğin 1972 yılında yayınlanan Marland raporunda; zihinsel, akademik, üretkenlik, yaratıcılık, liderlik, sanat ya da psikomotor alanlarından en az birinde olağanüstü başarı gösteren bireyler için üstün zekalı ve yetenekli bireyler olarak bir betimlemeye gidilmiştir (Marland, 1972).

Türkiye'de Milli Eğitim Bakanlığı Özel Eğitim Konseyi'nin 1991 yılındaki yaptığı açıklamada "üstün zekâ" ve "üstün özel yetenek" kavramları "üstün yetenek" şeklinde tek çatı altında birleştirilmiştir (MEB, 1991). Ancak yıllar içerisinde benzer anlam yüküne sahip yeni kavramlar ile nitelendirilmeye devam edilmiştir. Nitekim Milli Eğitim Bakanlığı tarafından 2016 yılında yayınlanan Bilim ve Sanat Merkezleri (BİLSEM) yönergesinde, özel yetenekli bireyler için "yaşıtlarına göre daha hızlı öğrenen; yaratıcılık, sanat, liderliğe ilişkin kapasitede önde olan, özel akademik yeteneğe sahip, soyut fikirleri anlayabilen, ilgi alanlarında bağımsız hareket etmeyi seven ve yüksek düzeyde performans gösteren birey" olarak tanımlama yapılmıştır (MEB Bilim ve Sanat Merkezleri Yönergesi, 2016, s. 450). Bununla birlikte üstün yetenek kavramı tanımlanırken farklı ifadelerin kullanıldığ 1 da dikkat çekmektedir. Örneğin Renzulli (1978) üstün yeteneği üç halka kuramı bağlamında ele almaktadır. Bu kurama göre, her bir halka yaratıcılık, motivasyon ve ortalama üstü özel/genel yeteneği temsil etmekte, halkaların etkileşimi üstün yeteneğin bir göstergesi olarak kabul edilmektedir. Sak'a (2011) göre, üstün yetenek; "insanlık yaşamı için temel değeri olan ve tanımlanmış yetenek alanlarında sahip olunan olağanüstü potansiyel" olarak belirtilmektedir (s. 216). Winner (1996) belirli bir alandaki performansı, yaratıcılığı, sorumluluğu ve becerileri yüksek düzeyde olan bireyleri üstün yetenekli bireyler olarak ifade etmektedir. Bu bağlamda, mantıksal ilişki kurma, hayal gücüne ve cesarete sahip olma, sorgulama ve iletişim becerilerini etkili kullanma ve genelleştirme yapabilme gibi özellikler üstün yetenekli bireylerin tipik davranışları arasında gösterilmektedir (Reis \& Renzulli, 2010). Ayrıca yaratıcılık, analitik ve pratik düşünme becerileri üstün yetenek göstergeleri olarak nitelendirilmektedir (Renzulli, 2012; Sternberg, 2000). Bu bakımdan bu göstergelere sahip bireyler hem yaşıtlarına göre daha bilgilidir hem de problem çözme, analiz ve sentez yapma becerileri daha gelişmiş düzeydedir (Metin, 1999). 
Üstün zekalı ve özel yetenekli bireylerin ülkelerin geleceğinin şekillenmesinde büyük umutlar vaat ettiği yadsınamaz bir gerçektir (Genç, 2016). Dolayısıyla bu bireyler, toplumları için önemli bir değer ve paha biçilmez bir hazinedir. Çünkü bilimsel ve ekonomik faaliyetler, bilişim ve enformasyon sistemleri, teknolojik ilerlemeler, sanatsal çalı̧̧malar ve daha pek çok alan onların itici gücü sayesinde daha fazla gelişim göstermektedir (Kulaksızoğlu, 2004; Özyaprak, 2016). Bundan dolayı üstün yetenekli bireylerin gelişimlerine eğitim yoluyla katkı sağlamak insanlığa daha fazla katkı sağlamak anlamına gelmektedir. Özellikle son otuz yıllık süreç içerisinde nitelikli insan gücüne duyulan gereksinimin artmasıyla birlikte yetenekli öğrencilerin daha nitelikli eğitim almaları konusundaki çalışmalar pek çok ülkede hız kazanmıştır (Önal \& Büyük, 2020). Ulusların geleceklerinin sahip oldukları bireylerin yeteneklerini geliştirilmekle yakından ilgili olması bu sürece daha fazla ivme katmıştır (MEB, 2019). Günümüzde birçok ülkede üstün zekalı ve özel yetenekli bireylerin eğitiminde önemli ilerlemeler sağlanmıştır. Bu bireylerin gelişimlerine daha fazla destek olmak için öğretim modelleri tasarlanmakta, programlar ve müfredatlar oluşturulmakta, materyaller geliştirilmekte, ders tasarımları üretilmekte, farkındalığı artırıcı bilgilendirmeler yapılmakta, zenginleştirilmiş öğrenme ortamları sunulmakta aynı zamanda yoğun bilimsel faaliyetler yürütülmektedir (Ataman, 2004; Brulles vd., 2010; Davaslıgil, 1995; Dönmez \& İdin, 2017; Gagne, 2004; MEB, 2017; National Association for Gifted Children [NAGC], 2008; Reis \& Renzulli, 2003; Sak, 2014; VanTassel-Baska, 1997). Türkiye'de de üstün zekalı ve özel yetenekli bireylerin daha iyi eğitilmesi konusunda önemli adımlar atılarak, başta Bilim ve Sanat Merkezlerinin (BILLSEM) sayılarının artırılması olmak üzere matematik, fen, mühendislik, sanat ve eğitim bilimleri gibi alanlarda farklılaştııılmış öğretim strateji ve uygulama örneklerine daha fazla ağırlık verilen çalışmalar yürütülmektedir (Ataman, 2004; Dönmez \& İdin, 2017; MEB, 2016; Özyaprak, 2015; Sak, 2011).

Türkiye'de matematik eğitimi alanında üstün zekalı ve özel yetenekli öğrencileri konu edinen çalışmalar genel olarak irdelendiğinde, tanılama çalışmalarının yanı sıra bu öğrencilere yönelik öğretim uygulamalarının ağırlıkta olduğu görülmektedir (Akay, 2018; Altıntaş, 2014; Battal-Karaduman, 2012; Budak, 2007; Dağlığlu, 2002; Karataş, 2013; Kök, 2012; Özçelik, 2017; Özyaprak, 2016; Özyaprak ve Davaslıgil, 2015; Taş, 2018; Türk, 2018). Bunların dışında eleştirel düşünme, başarı, kaygı, öz-yeterlik, uzamsal yetenek, işlemsel düşünme, problem çözme, akıl yürütme, üstbilişsel farkındalık, akademik benlik, matematiksel düşünme, yaratıcllık, ispat yapma, tutum, erişi ve soru sorma becerileri gibi pek çok değişkenler yardımıyla ele alınan çalışmalar da bulunmaktadır (Akkaş, 2014; Altıntaş, 2009; Aygün, 2019; Boran, 2016; Dinamit, 2020; Durmaz, 2014; Ergut, 2019; Gürel, 2011; Hızll, 2013; İnanır, 2019; Karataş, 2013; Kök, 2012; Taş, 2018; Taşkın, 2016; Yılmaz, 2019). Türkiye'de üstün zekalılar ve özel yetenekliler alanına yönelik çalışmalar günümüzde artmasına rağmen yürütülen çalışmalarda deneysel ve uygulamaya yönelik çalışmaların yeterli düzeyde olmadığı ve belirli çerçeveler dışına çıkamadığ belirtilmektedir (Ayvacı \& Bebek, 2019; Koçak, 2020). Bu duruma dikkat çeken Nacar (2015), Türkiye'de matematik eğitimi alanında üstün zekalılar ve özel yeteneklileri konu edinen az sayıdaki çalışmalarda genellikle nicel yöntemin daha fazla tercih edildiğini ve t-testi ile nitel analizlerin sıklıkla kullanıldığını dile getirmektedir. Benzer şekilde, Ayvacı ve Bebek (2019) tarafından yapılan çalışmada da Türkiye'de üstün zekalı ve özel yetenekli konusunda nicel ve alan taramasına yönelik çalışmaların daha fazla kullanıldığı belirlenmiştir. Yapılan çalışmalarda genellikle üstün zekalı ve özel yetenekli bireylerin özelliklerini ve becerilerini belirleme konularının tercih edildiğini tespit etmişlerdir. Bir diğer çalışmada ise Özenç ve Özenç (2013) tarafından 1995'ten 2012 yılına kadar Türkiye'de üstün yetenekli öğrencilere yönelik yapılan lisansüstü tezler incelenmiştir. Çalışma sonucunda, yöntem olarak nicel, model olarak tarama ve veri toplama araçları olarak da ölçek ile anketin daha fazla kullanıldığı rapor edilmiştir. Güçin ve Oruç (2015) tarafından yapılan çalışma sonunda ise Türkiye' de üstün zekâlılar ve yetenekliler ile ilgili akademik çalışmaların çoğunlukla bildirilerden oluştuğu belirlenmiştir. Ayrıca üstün zekalı ve özel yetenekli bireylere yönelik durum saptama ile eğitimlerini konu edinen çalışmaların daha fazla olduğu tespit edilmiştir.

Türkiye' de özellikle son zamanlarda matematik eğitiminde üstün zekalıları ve özel yeteneklileri konu edinen tez çalışmalarının giderek artmasına rağmen ilgili alanyazında bu tezlerin gerek tematik 
gerekse metodolojik eğilimlerin incelendiği kısıtlı sayıda çalışmaların bulunması araştırmanın önemine vurgu yapmaktadır. Aynı zamanda bu alanda yapılan çalışmaların yıllar içerisindeki değişimlerinin neler olduğunun ve nasıl bir eğilim sergilediklerinin belirlenebilmesi açısından bu tür çalışmaların süreklilik arz etmesi de çalışmanın gerekliliğini ortaya koymaktadır. Yürütülen tezlerin bütüncül bir bakış açısıyla ortaya konması ve mevcut durumun çerçevesinin çizilmesi bu alanda çalışan veya çalışma yapacak araştırmacılara yol göstermesi açısından değerli olduğu düşünülmektedir. Bu bağlamda, çalışma kapsamında Türkiye' de matematik eğitiminde üstün zekalılar ve özel yetenekliler konusunda yapılmış lisansüstü tezlerin hem tematik hem de metodolojik açıdan eğilimlerinin neler olduğunun incelenmesi amaçlanmıştır. Tematik açıdan tezlerin amaçları, problem cümleleri, çalışma konuları, yayın yılları ve türleri (yüksek lisans ve doktora) ele alınmıştır. Diğer taraftan metodolojik açıdan ise tezlerin yaklaşımları, yaklaşım açıklamaları, örneklem düzeyleri, veri toplama araçları ve veri analiz açıklamaları ele alınmıştır. Bu sayede matematik eğitiminde üstün zekalılar ve özel yetenekliler konusu ile yapılmış lisansüstü tezlerdeki eğilimlerin sistematik bir şekilde belirlenmesi hedeflenmiştir. Elde edilen bulgular ışığında, yapılmış tezlerin ortak yönleri ve farklılıkları belirlenerek mevcut durum ortaya çıkarılmaya çalışılmıştır. Ayrıca bu çalışmanın özellikle matematik eğitiminde üstün zekalılar ve özel yetenekliler konusunda çalışma yapan ya da yapacak araştırmacılara hem kaynak oluşturması hem de yol gösterici olması umulmaktadır. Bu çalışmanın benzer çalışmalara fikir vermesinin yanı sıra özgün bir şekilde geliştirilmelerine ve çıkarımlarda bulunmalarına da destek olması beklenmektedir. Bu doğrultuda, çalışmada aşağıdaki problemlere yanıtlar aranmıştır:

1. Türkiye'de matematik eğitimi alanında üstün zekalılar ve özel yetenekliler konusunda yürütülmüş lisansüstü tezlerin tematik açıdan genel özellikleri nelerdir?

a) Çalışmalarda hangi amaçlara ulaşılmak istenmiştir?

b) Çalışmalarda hangi konular ele alınmıştır?

c) Çalışmaların yıllara göre dağılımı nasıldır?

d) Çalışmaların türlerine göre dağılımı nasıldır?

2. Türkiye'de matematik eğitimi alanında üstün zekalılar ve özel yetenekliler konusunda yürütülmüş lisansüstü tezlerin metodolojik açıdan genel özellikleri nelerdir?

a) Çalışmaların yaklaşımlarına ve yaklaşım açıklamalarına göre dağılımı nasıldır?

b) Çalışmaların örneklem düzeylerine göre dağılımı nasıldır?

c) Çalışmaların veri toplama araçlarına göre dağılımı nasıldır?

d) Çalışmaların veri analiz açıklamalarına göre dağılımı nasıldır?

\section{Yöntem}

\section{Araştırma Modeli}

$\mathrm{Bu}$ araştırma kapsamında matematik eğitimi alanında üstün zekalılar ve özel yetenekliler konusunda Kasım 2020 tarihine kadar yürütülmüş lisansüstü tezler tematik ve metodolojik açıdan sistemik bir şekilde ele alınmıştır. Bu sayede bu alanda yürütülmüş çalışmaların eğilimlerin neler olduğu belirlenmeye çalışılmıştır. Nitel bir anlayışa bağlı olarak ele alınan çalışmada doküman incelemesi yapılarak lisansüstü tezler incelenmiş ve betimlenmeye çalışılmıştır. Doküman incelenmesi, araştırmaya konu olan olgu ve olaylar hakkında bilgiler barındıran yazılı materyallerin analizini içermektedir (Yıldırım \& Şimşek, 2018). Dokümanlar, geçerli ve güvenilir çıkarımlar yapmak için etkili bir şekilde kullanılması gereken önemli bilgi kaynaklarıdır (Krippendorff, 2013; Yıldırım \& Şimşek, 2018). Dokümanların incelenmesinde betimsel içerik analizi kullanılmıştır. Betimsel içerik analizi, belirli bir konu üzerinde yürütülen çalışmaların ele alınıp eğilimlerinin belirlenmeye çalışıldığı sistematik çalışmalardır (Çalık \& Sözbilir, 2014). Bu analizin amacı, elde edilen verileri bir düzen dahilinde ve yorumlanmış bir biçimde okuyucuya sunmaktır (Yıldırım \& Şimşek, 2018). Bu sayede nitel ve nicel çalışmalardan elde edilen veriler sistematik ve açık bir şekilde betimlenerek genel eğilimlerin neler olduğu belirlenmeye çalışılır (Cohen vd., 2007; Selçuk vd., 2014). Bu çalışmada, Yükseköğretim Kurulu Ulusal Tez Merkezi veri tabanında araştırmaya konu olan erişime izinli lisansüstü tezler incelenmiştir (URL-1: www.tez.yok.gov.tr). 


\section{Veri Toplama Aracı}

Çalışma kapsamında öncelikle Türkiye'de matematik eğitiminde üstün zekalılar ve özel yetenekliler konusunda yapılmış lisansüstü tezlerin hangi kriterlere göre seçileceği belirlenmiştir. Bu bağlamda, incelenmesi planlanan çalışmaların Türkiye'de yürütülmüş lisansüstü tezleri kapsaması ve erişim izninin olması birincil kriterler olarak belirlenmiştir. Bir diğer adımda, alanyazındaki üstün zekalılar ve özel yetenekliler konusu ile yürütülmüş çalışmalar incelenerek anahtar kelimeler belirlenmeye çalışılmıştır. İlgili alanyazındaki çalışmaların ön incelenmesi tamamlandıktan sonra üstün, yetenek, bilim ve sanat merkezleri (BILLSEM) kelimeleri anahtar sözcükler olarak belirlenmiştir. Ayrıca bu sözcüklerin ingilizce karşılıkları olan gifted, talented, science and art centers (SAC) kelimeleri de taramada kullanılarak daha fazla çalışmaya ulaşmaya imkân tanıyan bir anlayışla hareket edilmeye çalışılmıştır. Daha sonra lisansüstü tezler Ulusal Tez Merkezi veri tabanından yazar ad/soyadı ve yayınlanma tarihlerine göre bilgisayarda oluşturulan bir klasör içerisine kod verilerek kayıt edilmiştir. Bu işlemin ardından her bir çalışma matematik eğitimi alanında olup olmadığına göre araştırmacı tarafından iki kere gözden geçirilerek yeniden tasnif edilmiştir. Bu işlemin ardından tezlerin tanımlayıcı künyesinin (tez adı, tezin amacı, yayın yılı, türü), yönteminin, veri toplama araçlarının, örnekleminin ve veri analiz açıklamalarının yer aldığı ayrıntılı bir Lisansüstü Tez Çalışmaları Tasnif Formu kullanılmıştır. Bu formun oluşturulmasında benzer çalışmalarda kullanılan formlarda incelenerek çalışmaya uygun bir çerçeve oluşturulmaya çalışılmıştır (Sözbilir vd., 2012). Bu aşamadan sonra çalışmanın araştırma problemleri doğrultusunda veri tabanından ulaşılan çalışmaların amaçları, alt problemleri yayın yılları, yayın türleri, yöntemleri, veri toplama araçları, örneklem düzeyleri ile veri analiz açıklamaları uyarlanan forma işlenmiştir. Form sınıflandırılmasının güvenirliğini artırmak için eğitim fakültesinde görevli bir öğretim üyesinden de yardım alınmıştır. İki kişi tarafından bağımsız olarak sınıflandırıldığı formun uzlaşma yüzdesinin tespiti için Miles ve Huberman'ın (1994) ifade ettiği Güvenirlik Katsayısı=Görüş Birliği $\div$ (Görüş Birliği+Görüş Ayrılığı)x100 hesaplanmıştır. Buna göre kodlayıcılar arasındaki görüş birliği her bir alt problemleri için \%90 ve üzeri olarak belirlenmiştir. Anlaşmazlık bulunan çalışmaların sınıflandırma güvenirliğini daha fazla artırmak için bu çalışmalar birlikte tekrar değerlendirilmiş ve anlaşmazlıklar giderilmiştir. Örneğin 31 numaralı çalışma için bilişsel gelişim isminde tek bir konu kategorisinin oluşturulmasına birlikte karar verilmiştir. Diğer yandan verilerin analizi sürecinde her bir lisansüstü tez çalışması her iki bağımsız kodlayıcı tarafından ayrıntılı ve dikkatli bir şekilde okunarak derinlemesine incelenmiştir. Bu sayede çalışmaların anlamlı ve doğru tanımlanması, tam ve doğru temsil edilmesi ve sonucunda verilerin doğru yorumlanması hedeflenerek araştırmanın geçerliğine katkı sağlanmak istenmiştir (Sandelowski \& Barrosa, 2007).

\section{Veri Analizi}

Çalışmada Yükseköğretim Kurulu Ulusal Tez Merkezi veri tabanından erişime izinli 53 lisansüstü tez seçilerek analiz edilmiştir (Ek-1). Çalışmaların analizi beş adımda gerçekleştirilmiştir. Birinci adımda, çalışmanın amacına uygun olarak belirlenen tezler, yazar adları, soyadları ve yayınlanma yıllarına göre bilgisayardaki bir klasör içerisine kayıt edilmiştir. Sonrasında tezlerin her birine birden 53'e kadar numara verilmiştir. Tezlerin bu şekilde kod numarası verilmesindeki amaç ise yapılan inceleme ve analiz sürecinde kolaylık sağlamaktır. İkinci adım, tezlerin genel çerçevesini ortaya koyan tasnif formuna elde edilen verilerin girilmesi sürecini kapsamaktadır. Tasnif formuna tezlerin hangi amaçlara ulaşmak istediği, hangi konuları ele aldığı, yayın yılları, yayın türleri, yaklaşımları ve yaklaşım açıklamaları, örneklem düzeyleri, veri toplama araçları ve veri analiz açıklamalarına ait bilgiler her bir çalışma için ayrı ayrı yazılmıştır. Üçüncü adımda, her bir araştırma problemine göre elde edilen veriler ışığında gruplandırma yapılarak temalar ve kategoriler oluşturulmuştur. Dördüncü adımda kodlayıcılardan elde edilen veriler karşılaştııılarak tablolaştııılmış, son adımda ise tablolar halinde yer alan veriler grafiklere dönüştürülüp raporlandırılmıştır. Betimsel analiz sonucunda, incelemesi yapılan tezler belirlenen temalara, konu dağılımlarına ve kategorilerine göre oluşturulan grafikler yardımıyla okuyuculara sunulmuştur. 


\section{Bulgular}

Çalışmanın amacı doğrultusunda elde edilen bulgular iki bölüm halinde açılanmıştır. Birinci bölümde, Türkiye'de matematik eğitimi alanında üstün zekalılar ve özel yetenekliler konusunda yürütülmüş tezlerin tematik açıdan genel özelliklerinin belirlenmesi üç başlık altında incelenmiştir. İncelenen başlıklar ise şu şekildedir: (1) lisansüstü tezlerde ele alınan temaların neler olduğu, (2) lisansüstü tezlerde tercih edilen çalışma konularının neler olduğu, (3) lisansüstü tezlerin yıllarına ve türlerine göre dağılımlarının nasıl olduğu şeklindedir. İkinci bölümde ise Türkiye' de üstün zekalılar ve özel yetenekliler konusunda yürütülmüş lisansüstü tezlerin metodolojik açıdan genel özelliklerinin belirlenmesi dört başlık altında incelenmiştir. İncelenen başlıklar ise şu şekildedir: (1) lisansüstü tezlerin yaklaşımlarına ve yaklaşım açıklamalarına göre dağılımların neler olduğu, (2) lisansüstü tezlerin örneklem düzeylerine göre dağılımların neler olduğu, (3) lisansüstü tezlerin veri toplama araçlarına göre dağılımların neler olduğu, (4) lisansüstü tezlerin veri analiz açıklamalarına göre dağılımların neler olduğu şeklindedir.

\section{Türkiye'de Matematik Eğitimi Alanında Üstün Zekalılar ve Özel Yetenekliler Konusunda Yürütülmüss Lisansüstü Tezlerin Tematik Açından Genel Özellikleri}

\section{Lisansüstü Tezlerde Ele Alınan Temalarn Belirlenmesi}

Türkiye'de matematik eğitimi alanında üstün zekalılar ve özel yetenekliler konusunda yürütülmüş lisansüstü tezlerin temalarını tespit etmek için yürütülen çalışmaların amaçlarının yanı sıra alt problemlerinin neler olduğuna bakılmıştır. Bu doğrultuda yürütülen her bir çalışmanın temel amaçlarının neler olduğu belirlenmeye çalışılmıştır. Bu temel amaç ise lisansüstü tezlerin araştırmasına konu olan problemlere bağlı olarak elde etmek istediği genel hedefleri yansıtmaktadır. Çalışmalardan elde edilen temel amaçlara göre lisansüstü tezlerin dört farklı tema altında birleştiği belirlenmiştir. Belirlenen bu temalar ise (1) üstün zekalı ve özel yetenekli öğrencileri tespit etme çalışmaları, (2) üstün zekalı ve özel yetenekli öğrencilere yönelik yürütülen eğitim-öğretim faaliyetleri, (3) üstün zekalı ve özel yetenekli öğrencileri farklı değişkenler bağlamında ele alma çalışmaları ve (4) üstün zekalı ve özel yetenekli öğrencileri merkeze alan değerlendirme çalışmaları şeklindedir.

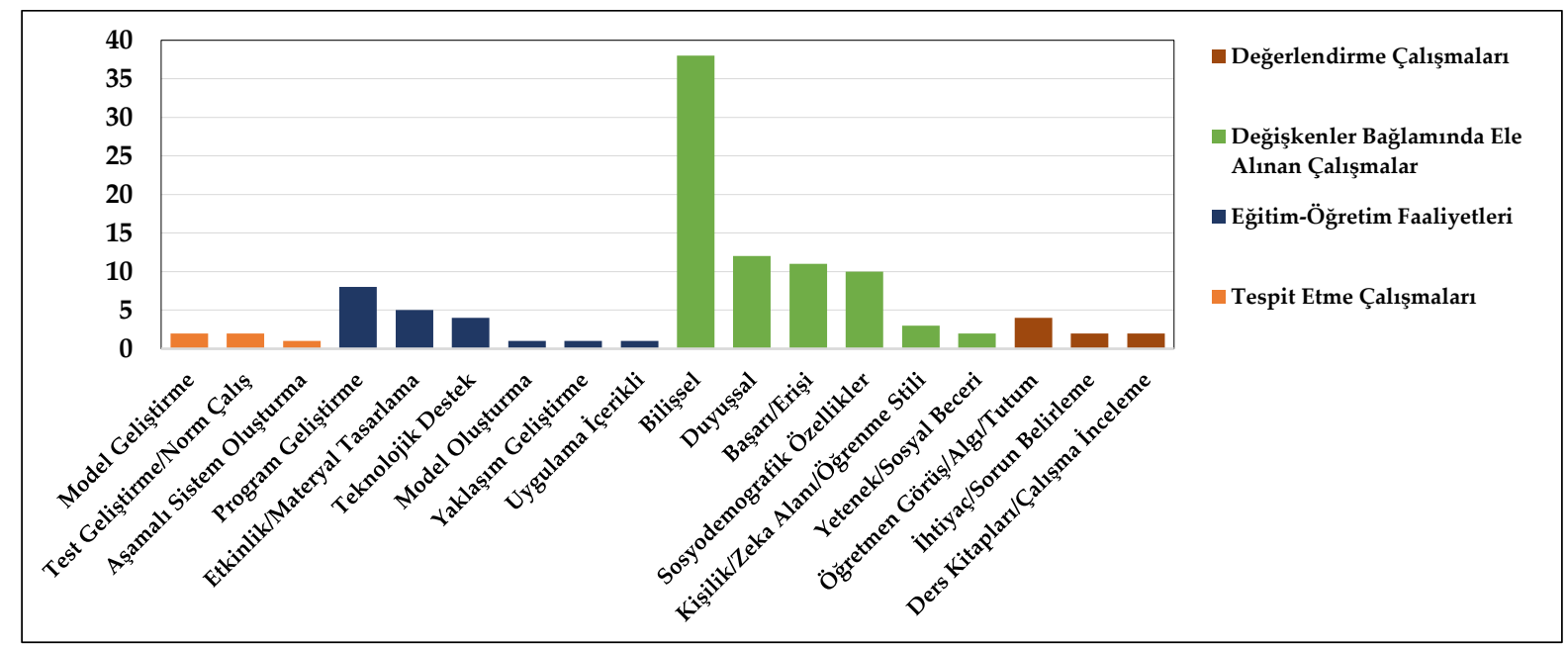

Şekil 1. Üstün Zekalılar ve Özel Yetenekliler Konusunda Yürütülen Tezlerdeki Temalar

Şekil 1'de görüldüğü üzere yapılan tez çalışmalarında en fazla üstün zekalı ve özel yetenekli öğrencilerin bilişsel özelliklerini (38) (problem çözme, akıl yürütme, bilişüstü, bilimsel süreç, yaratıcllık, eleştirel, yansıtıcı, kritik, işlemsel, matematiksel ve uzamsal düşünme becerileri vb.) konu edinen çalışmalar araştırılmıştır. Bu çalışmaları üstün zekalı ve özel yetenekli öğrencilerin duyuşsal özellikleri (12) ile başarı/erişi düzeylerini (11) konu edinen çalışmalar takip etmektedir. Ayrıca üstün zekalı ve özel 
yetenekli öğrencilerin sosyodemografik özelliklerinin (10) ele alındığı çalışmalar ile bu öğrenciler için programların geliştirildiği (8) çalışmaların sayısı da dikkat çekmektedir. Bunların yanı sıra üstün zekalı ve özel yetenekli öğrencilere yönelik etkinliklerin, materyallerin tasarlandığı veya geliştirildiği (5) çalışmalar ile öğretmenlerin öğretim programına ve uygulamaya yönelik görüşlerini, üstün zekalı öğrencilere yönelik algılarını ve öğrencilerin eğitimlerine yönelik tutumlarını (4) içeren çalışmalar da ele alınmıştır. En az tercih edilen temalar, üstün zekalı ve özel yetenekli öğrencilerin tespit edilmeye çalışıldığı aşamalı sistem oluşturma (1), bu öğrencilerin eğitimleri ve öğretimleri için model oluşturma (1), uygulama içerikli çalışmalar yapma (1), yaklaşım geliştirme (1) ile kişilik tipi/zekâ alanı/öğrenme stili değişkenleri bağlamında (1) ele alınan çalışmalar olmuştur.

\section{Lisansüstü Tezlerde Ele Alınan Çalışma Konularının Belirlenmesi}

Türkiye'de matematik eğitimi alanında üstün zekalılar ve özel yetenekliler konusunda yürütülmüş tezlerin çalışma konularını belirlemek için yürütülen çalışmaların yöntemleri başta olmak üzere veri toplama araçlarına, uygulama süreçlerine ve eklerine bakılmıştır. Bu doğrultuda, yürütülen her bir çalışmaya ait içerik çerçevesi oluşturulmuş ve bu çerçeveye bağlı olarak çalışma konuları belirlenmeye çalışılmıştır. Elde edilen bulgulara göre, çalışma konularının iki farklı tema altında toplandığ etkinlikleri veya aktiviteleri içeren ile belirli bir öğrenme alanına yönelik matematik etkinlikleri veya aktiviteleri içermeyen çalışma konularından oluşmaktadır. Buna göre, öğrenme alanına yönelik matematik etkinlikleri veya aktiviteleri içeren kategoriye ait 30 çalışma yer alırken herhangi bir matematik etkinliği veya aktivitesi içermeyen kategoriye ait çalışma sayısı ise 23'dür. Elde edilen bulgulara göre, lisansüstü çalışmalarda elde edilen çalışma konuları; sayılar ve işlemler, sayılar ve cebir, cebir, geometri ve ölçme, veri işleme, olasılık ile erken eğitim programı kapsamında problem çözme becerileri kazandırmaya yönelik becerileri içeren yedi farklı öğrenme alanını kapsamaktadır. Belirli bir öğrenme alanı ekseninde yürütülen 30 çalışmaya ait öğrenme alanları ile alt öğrenme alanlarını içeren bilgiler Şekil 2'de sunulmuştur.

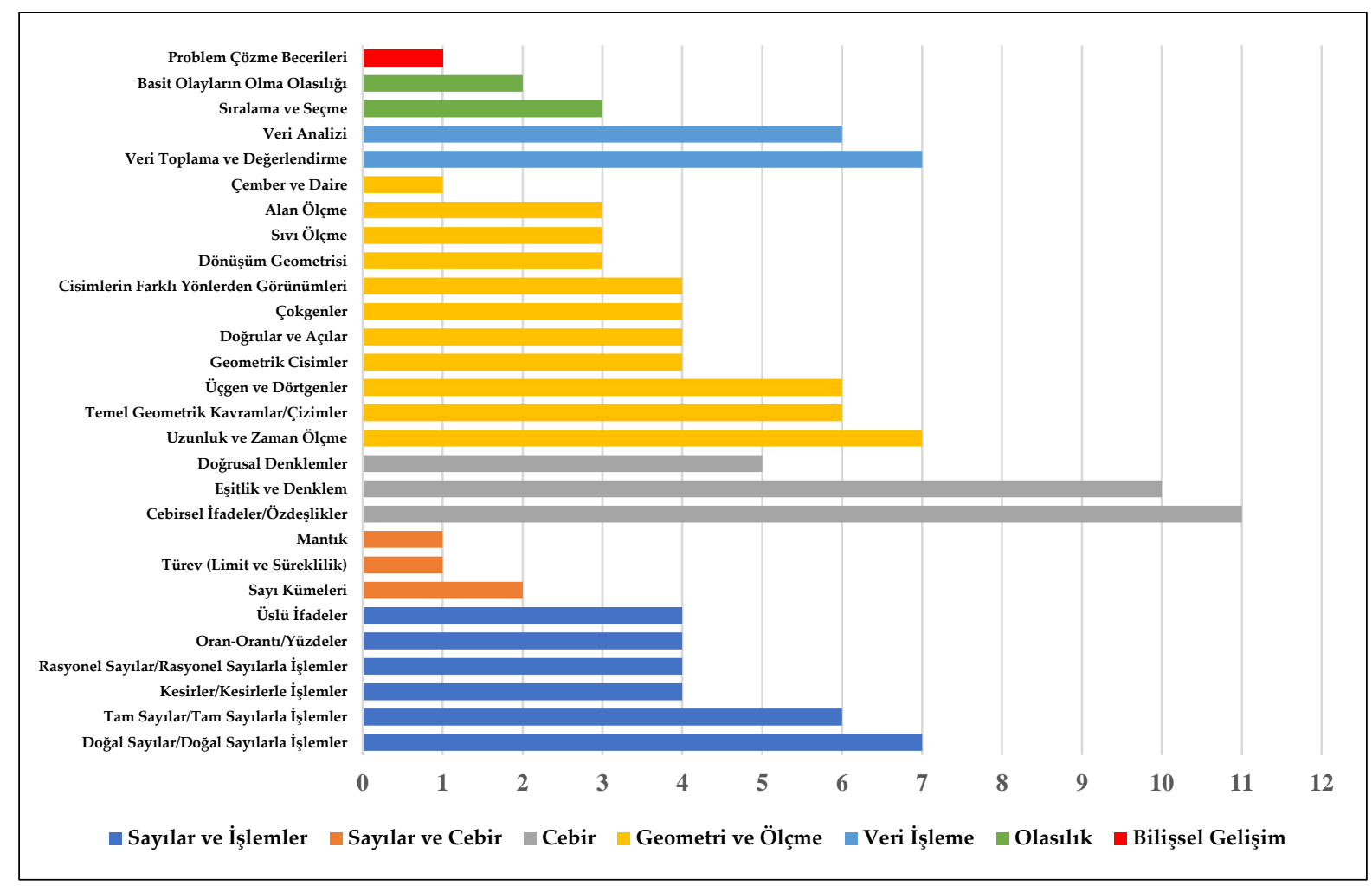

Şekil 2. Tezlerde Tercih Edilen Çalışma Konuları 
Şekil 2 incelendiğinde, yürütülen lisansüstü tez çalışmalarında en fazla cebir öğrenme alanı içerisinde yer alan cebirsel ifadeler/özdeşlikler (11) ile eşitlik ve denklem (10) konularının ele alındığı görülmektedir. Bu çalışmaları sayılar ve işlemler öğrenme alanı içerisinden doğal sayılar/doğal sayılarla işlemler (7), tam sayılar/tam sayılarla işlemler (6), geometri ve ölçme öğrenme alanı içerisinden uzunluk ve zaman ölçme (7), temel geometrik kavramlar ve çizimler (6) ile üçgen ve dörtgenler (6), veri işleme öğrenme alanı içerisinden veri toplama ve değerlendirme (7) ve veri analizi (6) konuları takip etmektedir. En az tercih edilen çalışma konuları ise sayılar ve cebir öğrenme alanı içerisinden türev (1), mantık (1), sayı kümeleri (2), geometri ve ölçme alanı içerisinden çember ve daire (1), olasılık öğrenme alanı içerisinden basit olayların olma olasılığı (2) şeklindedir. Ayrıca erken eğitim programı kapsamında bilişsel gelişim alanında yer verilen problem çözme becerileri (1) konusu da az sayıda tercih edilenler arasındadır.

\section{Lisansüstü Tezlerin Yıllarına ve Türlerine Göre Dağılımlarının Belirlenmesi}

Türkiye'de matematik eğitimi alanında üstün zekalılar ve özel yetenekliler konusunda yürütülmüş lisansüstü tezlerin yıllarına ve türlerine (yüksek lisans ve doktora) göre dağılımı aşağıdaki şekilde belirtilmiştir (Şekil 3).

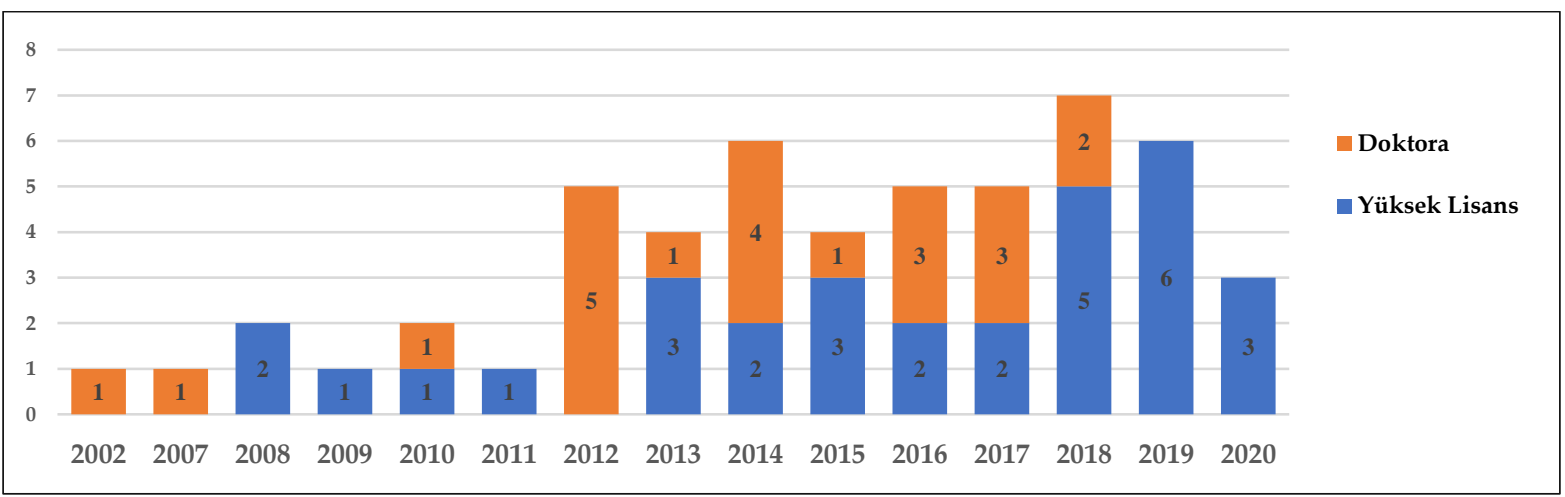

Şekil 3. Tezlerin Yıllarına ve Türlerine Göre Dağılımı

Şekil 3'deki matematik eğitiminde üstün zekalılar ve özel yetenekliler konusunda yürütülmüş lisansüstü tezlerin dağılımı incelendiğinde, yüksek lisans (31) ile doktora (22) çalışmaların dengeli bir şekilde dağılmadığı dikkat çekmektedir. Bazı yıllarda $(2008,2009,2011,2019,2020)$ sadece yüksek lisans bazı yıllarda $(2002,2007,2012)$ sadece doktora çalışmalarının yürütüldüğü görülmektedir. Çalışmanın Kasım 2020 yılına kadar sisteme kayıtlı ve erişime açık olan tezler ile yürütülmüş olması da dikkate alındığında yıllara göre dalgalanmaların olduğu görülmektedir. En fazla doktora çalışması (5) 2012 yılında, en fazla yüksek lisans çalışması (6) ise 2019 yılında yürütülmüştür. 2018 yılında ise 5 yüksek lisans ve 2 doktora çalışması ile bu alanda yürütülmüş en fazla çalışmaya ulaşılmıştır.

Türkiye'de Matematik Eğitimi Alanında Üstün Zekalılar ve Özel Yetenekliler Konusunda Yürütülmüş Lisansüstü Tezlerin Metodolojik Açından Genel Özellikleri

Bu bölümde, Türkiye'de matematik eğitim alanında üstün zekalılar ve özel yetenekliler konusunda yürütülmüş lisansüstü tezlerde yer alan yaklaşımlara, örneklem düzeylerine, veri toplama araçlarına ve veri analiz açıklamalarına ait elde edilen bulgulara yer verilmiştir.

\section{Lisansüstü Tezlerde Kullanılan Yaklaşımların ve Açıklamalarının Belirlenmesi}

Türkiye'de matematik eğitim alanında üstün zekalılar ve özel yetenekliler konusunda yürütülmüş lisansüstü tezler yaklaşımlarına göre incelendiğinde nicel, nitel ve karma yöntem olmak üzere üç kategori altında toplandığı tespit edilmiştir. Aşağıdaki şekilde bu tezlerin kategorilere göre açıklamaların nasıl olduğu belirtilmiştir (Şekil 4). 


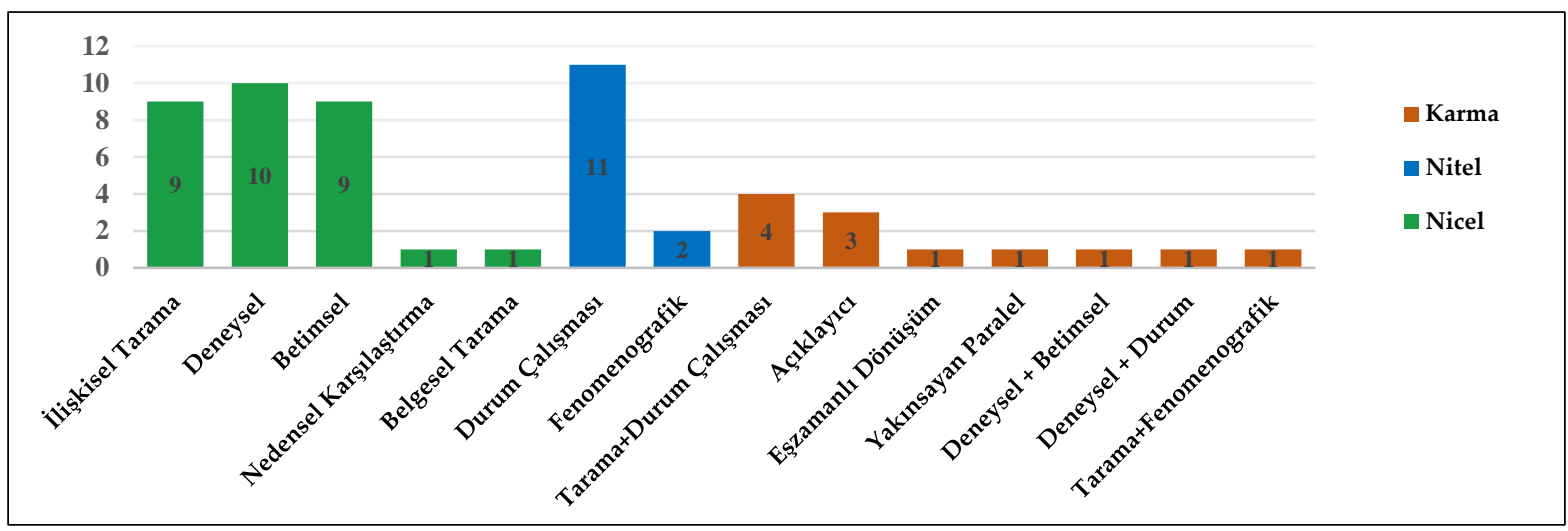

Şekil 4. Tezlerde Kullanılan Yaklaşımlar ve Açıklamaları

Şekil 4'deki matematik eğitiminde üstün zekalılar ve özel yetenekliler konusunda yürütülmüş lisansüstü tezlerin dağılımı incelendiğinde, lisansüstü tezlerde nicel araştırma yöntemlerin daha fazla tercih edildiği görülmektedir. Birden fazla araştırma desenlerin de tercih edildiği yaklaşımlarla birlikte yürütülen çalışmaların $\% 54,54^{\prime}$ ü nicel, $\% 23,64^{\prime}$ ü nitel ve $\% 21,82^{\prime}$ si karma yaklaşımlar ile yürütülmüştür. Nicel araştırma yöntemleri içerisinden deneysel (10), ilişkisel tarama (9) ve betimsel (9) desenlerin sıklıkla kullanıldığı dikkat çekmektedir. Nitel araştırma yaklaşımları içerisinden ise yürütülen çalışmalarda sadece durum çalışması (11) ve fenomenografik (olgu bilim) (2) desenleri kullanılmıştır. Karma yöntemin kullanıldığı çalışmalarda ise tarama ve durum çalışması (4) birlikteliğinden oluşan çalışmalar ile açıklayıcı karma (3) desen içerikli çalışmalar daha fazla tercih edilmiştir. Diğer yandan nedensel karşılaştırma, belgesel tarama, eşzamanlı dönüşüm, yakınsayan paralel, deneysel + betimsel, deneysel + durum, tarama + fenomenografik desenli çalışmalarda birer kez kullanılmıştır.

\section{Lisansüstü Tezlerde Kullanılan Örneklem Düzeylerinin Belirlenmesi}

Türkiye'de matematik eğitim alanında üstün zekalılar ve özel yetenekliler konusunda yürütülmüş lisansüstü tezler örneklem düzeylerine göre incelendiğinde; öğrenciler, öğretmen ve diğer (akademisyen/uzman, idareci/yönetici, doküman incelenmesi, veliler) olmak üzere üç kategori altında toplandığı tespit edilmiştir. Aşağıdaki şekilde bu tezlerin kategorilere göre açıklamaların nasıl olduğu belirtilmiştir (Şekil 5).

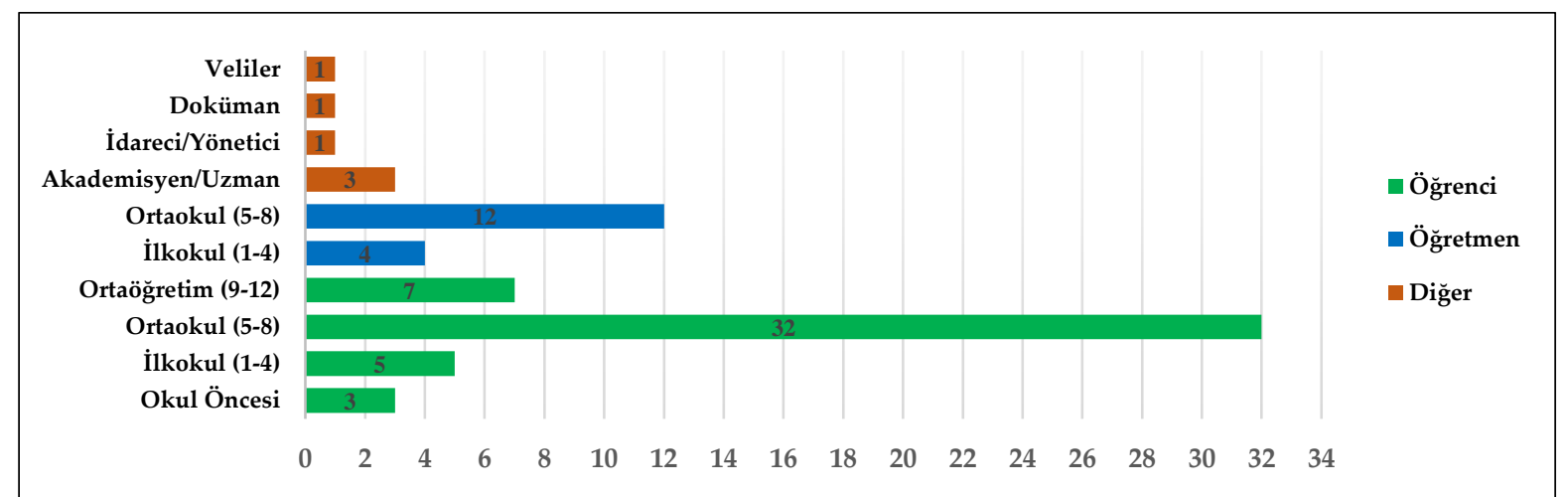

Şekil 5. Tezlerin Örneklem Düzeylerine Göre Dağılımı

Şekil 5'deki matematik eğitiminde üstün zekalılar ve özel yetenekliler konusunda yürütülmüş lisansüstü tezlerin dağılımı incelendiğinde, lisansüstü tezlerde en fazla tercih edilen örneklem düzeyinin ortaokul öğrencilerine (32) ait olduğu görülmektedir. İkinci sırada tercih edilen örneklem profili ise ortaokul öğretmenlerinden (12) oluşmaktadır. Buna göre, çalışmaların büyük çoğunluğunun örneklem gruplarını öğrenciler (47) ve öğretmenler (16) oluşturmaktadır. Diğer yandan okul öncesi (3), akademisyen/uzman (3), idareci/yönetici (1), doküman incelenmesi (1) ile velilerden (1) oluşan çalışma grupları daha az tercih edilmiştir. 


\section{Lisansüstü Tezlerde Kullanılan Veri Toplama Araçlarının Belirlenmesi}

Türkiye'de matematik eğitim alanında üstün zekalılar ve özel yetenekliler konusunda yürütülmüş lisansüstü tezler veri toplama araçlarına göre incelendiğinde ölçek, test, envanter, görüşme, doküman, gözlem ve anket olmak üzere yedi kategori altında toplandığı tespit edilmiştir. Aşağıdaki şekilde bu tezlerin kategorilere göre açıklamaların nasıl olduğu belirtilmiştir (Şekil 6).

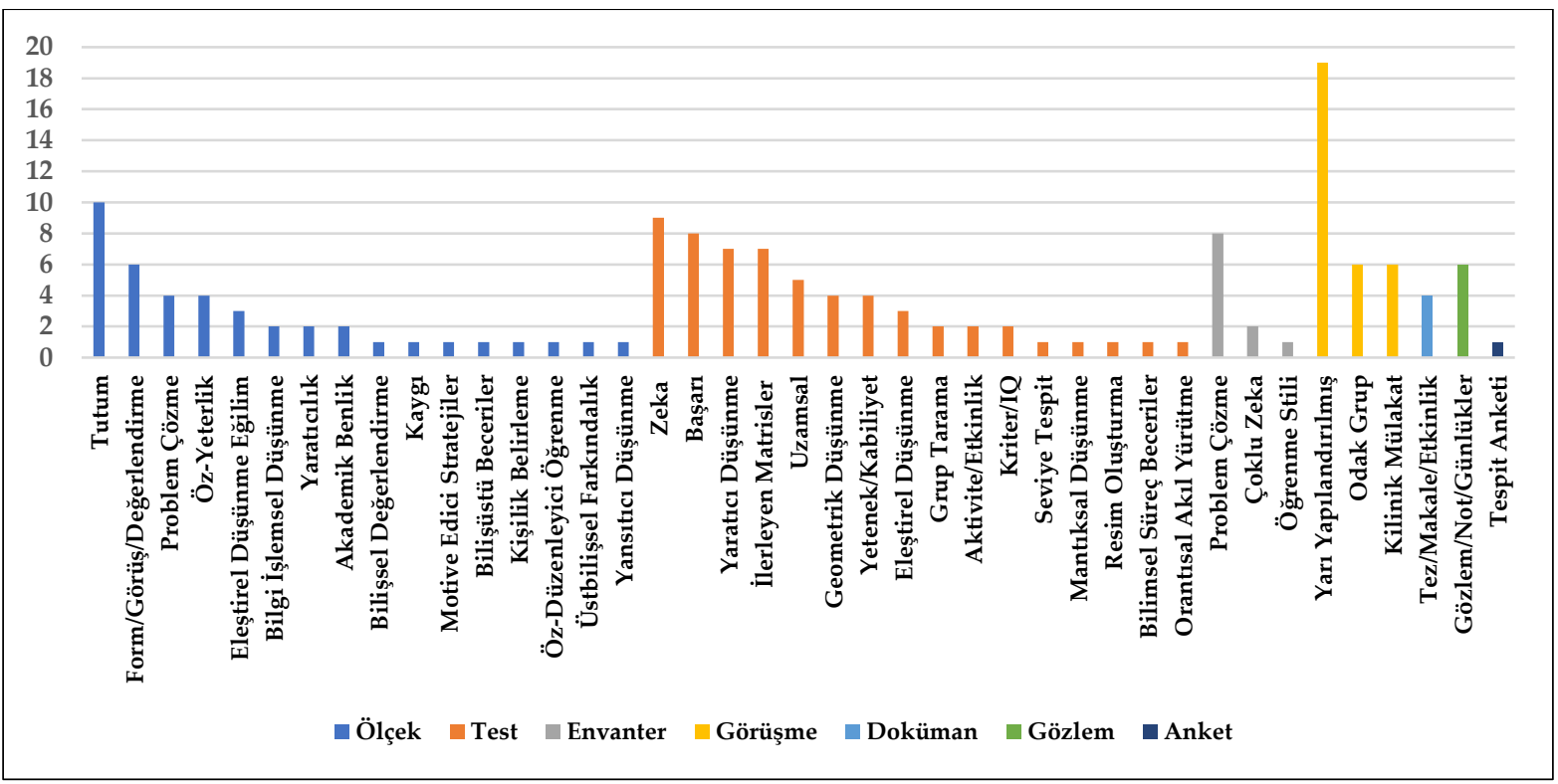

Şekil 6. Tezlerin Veri Toplama Araçlarına Göre Dağılımı

Şekil 6' daki matematik eğitiminde üstün zekalılar ve özel yetenekliler konusunda yürütülmüş lisansüstü tezlerin veri toplama araçlarına göre dağılımı incelendiğinde, en fazla tercih edilen veri toplama aracının yarı yapılandırmış görüşme (19) olduğu görülmektedir. Bunu sırasıyla tutum ölçeği (10), zekâ testi (9), başarı testi (8), problem çözme envanteri (8), standart ilerleyen matrisler testi (7), yaratıcı düşünme testi (7), form/görüş/değerlendirme ölçeği (6), odak grup görüşmesi (6), gözlem formu, notları ve günlükleri (6) takip etmektedir. Çeşitlilik açısından dikkate alındığında, ölçeklerin ve testlerin daha çok tercih edildiği dikkat çekmektedir. Diğer yandan tüm kategoriler içerisinden anketler en az tercih edilen veri toplama aracı olmuştur.

\section{Lisansüstü Tezlerin Veri Analiz Açıklamalarının Belirlenmesi}

Türkiye'de matematik eğitim alanında üstün zekalılar ve özel yetenekliler konusunda yürütülmüş lisansüstü tezlerin veri açılamaları incelendiğinde, nicel betimsel, nicel kestirimsel ve nitel olmak üzere üç kategori altında toplandığı tespit edilmiştir. Aşağıdaki şekilde bu tezlerin kategorilere göre açiklamaların nasıl olduğu belirtilmiştir (Şekil 7).

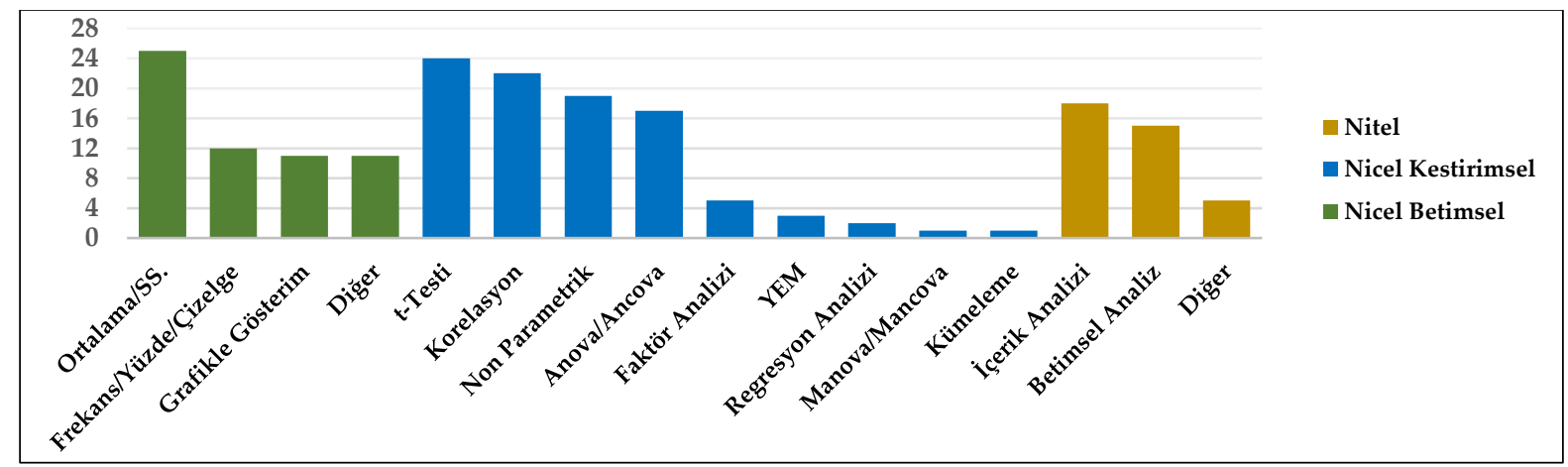

Şekil 7. Tezlerin Veri Açıklamalarına Göre Dağılımı 
Şekil 7'deki matematik eğitiminde üstün zekalılar ve özel yetenekliler konusunda yürütülmüş lisansüstü tezlerin veri açıklamalarına göre dağılımı incelendiğinde, nicel betimsel analiz içerisinden en fazla tercih edilenin ortalama, standart sapma (25), frekans, yüzde ve çizelge (12) ile grafikle gösterim (10) olduğu görülmektedir. Diğer yandan nicel kestirimsel analiz içerisinden t-Testi (24), korelasyon (22), non-parametrik testler (19), anova/ancova (17) analiz teknikleri daha fazla kullanılmıştır. Nitel analiz içerisinden ise içerik (18) ile betimsel (15) analiz teknikleri daha çok tercih edilmiştir. Bunların yanı sıra nicel betimsel analizleri içerisinden güvenirlik, madde ayırt ediciliği, ürün değerlendirme vb. (10) analiz teknikleri de kullanılmıştır.

\section{Tartışma, Sonuç ve Öneriler}

Bu çalışmada, Türkiye' de matematik eğitiminde üstün zekalılar ve özel yetenekliler konusunda yapılmış lisansüstü tezler hem tematik hem de yöntemsel açıdan incelenmiştir. Matematik eğitiminde üstün zekalı ve özel yetenekli öğrencilere yönelik yapılmış tezlerin amaç ve alt problem cümleleri analiz edildiğinde, tezlerin büyük çoğunluğunda öğrencilerin problem çözme, akıl yürütme, bilimsel süreç, bilişüstü, yaratıcılık, eleştirel, yansıtıcı, kritik, işlemsel ve uzamsal düşünme becerileri gibi değişkenler yardımıyla bilişsel özelliklerinin incelendiği belirlenmiştir. Hiç şüphesiz bu durumun temel nedenlerinden birisi üstün zekalı ve özel yetenekli bireylerin bilişsel özelliklerini daha iyi anlamaktır. Ancak çalışmaların büyük bir kısmında bu temaya yönelmiş olması üstün zekalı ve özel yetenekli bireyleri bütüncül bir açıdan incelemeyi sınırlandırmaktadır. Bundan dolayı bu bireylerin bilişsel özelliklerinin yanı sıra duyuşsal özelliklerini de içeren çalışmalara ağırlık verilmesi daha yararlı olabilir. Nitekim üstün zekalı ve özel yetenekli bireylerin akademik başarısını destekleyen bilişsel zekâ potansiyellerinin duygusal yönden de desteklenmesinin oldukça önemli olduğu bilinmektedir (Goleman, 2005). Araştırmacıları bu konuları araştırmaya yönelten bir diğer neden ise üstün zekalı ve özel yetenekli öğrencilerde daha çok bilişsel özelliklerin ön plana çıkması olabilir. Çünkü üstün zekalı ve özel yetenekli öğrenciler matematiğe ileri düzeyde ilgi duyarlar ve dünyayı matematiksel açıdan ele almayı ve yorumlamayı severler (Battal-Karaduman, 2012). Ayrıca bu bireylerin analiz ve sentezi iyi düzeyde yapmaları ve geniş bir bilgi yelpazesine sahip olmaları da matematik eğimi üzerine çalışan araştırmacıları bu konuları daha fazla araştırmaya yöneltmiş olabilir (Metin, 1999). Önal ve Büyük (2000) tarafından yapılan araştırmada, öğretmenlerin büyük çoğunluğu üstün zekalı çocukların üst düzey bilişsel kapasiteye sahip olduğunu belirtmiştir. Dolayısıyla bu bireylerin bilişsel özelliklerinin öğretmenler tarafından da sıklıkla vurgulandığı bilinmektedir. Bu ve benzeri çalışma bulguları ise araştırmacıların bu alana daha fazla yönelmelerine neden olmaktadır. Nitekim çalışmadan elde edilen bulgular da dikkate alındığında üstün zekalı ve özel yetenekli bireylerin sahip olduğu bilişsel gelişim özelliklerinin araştırmacılar tarafından da daha fazla merak edildiğini göstermektedir. Bu bağlamda, bu alanda yürütülecek benzer çalışmalarda öğrencilerin zihinsel özelliklerinin yanı sıra kişilik, fiziksel ve sosyal ve duygusal özelliklerine yer verilmesi önerilmektedir.

Araştırmanın bir diğer sonucunda, Türkiye'de matematik eğitiminde üstün zekalılar ve yetenekliler konusunda tespit etme ile değerlendirme çalışmalarını kapsayan temalarda daha az sayıda çalışmaların yürütüldügü belirlenmiştir. Buna göre, üstün zekalı ve özel yetenekli bireylerin öğretimleri için model, test ve yaklaşım geliştirme, aşamalı sistem oluşturma, öğretmen görüşlerine yer verme, ihtiyaç ve sorun belirleme ile ders kitaplarını incelemeye yönelik çalışmaların yeterli düzeyde olmadığı belirlenmiştir. Bu bakımdan, üstün zekalı ve özel yetenekli bireylerin daha nitelikli matematik öğrenmelerine imkân tanıyan ve içerisinde farklı öğrenme yaklaşımların da olduğu öğretim modelleri tasarlanabilir ayrıca bu bireylerin genel ihtiyaçlarının tespiti yapılarak öğrenme materyallerinin geliştirilmesine yönelik çalışmalar yürütülebilir. Araştırmanın dikkat çekici bulgularından birisi de eğitim-öğretim faaliyetleri teması içerisinde yer verilen uygulama içerikli çalışmaların sayısının yeterli düzeyde olmadığının belirlenmesidir. Bu bulgu, alanyazında dile getirilen uygulamaya yönelik çalışmaların Türkiye'de yeterli düzeyde yapılmadığına yönelik söylemlerle de örtüşmektedir (Ayvacı \& Bebek, 2019; Koçak, 2020). Bu yüzden matematik eğitiminde özellikle uygulama içerikli çalışmalara 
ağırlık verilmesi üstün zekalı ve yetenekli öğrencileri daha yakından tanıma fırsatı tanıyabilir. Dolayısıyla bu alanda yapılacak çalışmalarda uygulama gerektiren ders içi faaliyetler daha fazla yer alabilir. Özellikle bu bireylerin başta yaratıcılık ve yenilikçilik olmak üzere iş birliği, iletişim kurma, esneklik ve uyum, girişimcilik ve öz-yönetim, liderlik ve sorumluluk ile bilgi, medya ve teknoloji okuryazarlığı gibi 21. yüzyıl becerilerini ön plana çıkaracak çalışmalara odaklanılması gerekmektedir (NRC, 2011). Bu bağlamda öğrencilerin bilimsel süreç becerilerine katkı sunacak yaratıcı aynı zamanda girişimci etkinliklerin ve modellerin oluşturulması ve test edilmesi yararlı olacaktır. Bu doğrultuda, özellikle bireylerin bir konu hakkındaki öğrenme ürünlerini daha iyi ortaya çıkarmak adına farklı zaman dilimlerinde bireylerin tekrar incelenmesine olanak tanıyan boylamsal çalışmalar yapılabilir.

Matematik eğitimi alanında üstün zekalı ve özel yetenekli öğrencilere yönelik yapılan lisansüstü tezlerin analizinde ortaya çıkan bir diğer bulgu ise cebir öğrenme alanına çalışmalarda daha fazla yer verilmiş olmasıdır. Buna göre, cebirsel ifadeler ve özdeşlikler ile eşitlik ve denklemler konuları araştırmacılar tarafından daha çok tercih edilmiştir. Bu durumun birçok temel sebebi olmakla birlikte cebir öğrenme alanın yoğun bir zihinsel aktivite içermesi ve soyut düşünmeye kapı aralaması araştırmacıları bu konulara yöneltmiş olabilir. Çünkü cebir öğrenme alanı gerek içeriği gerekse sahip olduğu dinamik yapısı itibarıyla nicelikleri ve sayıları sembollerle temsil eden, denklem çözümlerini sembolleştiren, sayısal ilişki ve özellikleri gösteren hesaplama aracı olarak tanımlanmaktadır (Kieran, 1992). Bu yüzden matematiğin dilini temsil eden bu çalışma konusunun araştırmacılar tarafından daha çok tercih edilmesi şaşırtıcı bir durum değildir. Ancak türev, mantık, sayı kümleri, olasılık çember ve daire gibi çalışma konularının araştırmacılar tarafından daha az tercih edilmiş olması üstün zekalı ve özel yetenekli bireylerin farklı öğrenme alanlarındaki çalışma becerilerini daha iyi anlamamızı sınırlandırmaktadır. Bu yüzden matematik eğitiminde yapılacak çalışmaların farklı çalışma konuları ile zenginleştirilmesi daha yararlı olabilir. Bu sayede üstün zekalı ve özel yetenekli bireylerin farklı öğrenme alanlarındaki becerilerini daha iyi anlama fırsatı yakalanabilir.

Araştırmanın bir diğer bulgusu ise lisansüstü tezlerin yayın yılı ve türlerinin analizinden elde edilmiştir. Buna göre, yüksek lisans sayısının doktora çalışmalarından daha fazla olduğu belirlenmiş olsa da bazı yıllarda $(2002,2007,2012)$ sadece doktora çalışmalarının yürütüldüğü belirlenmiştir. Diğer yandan bazı yıllarda da $(2008,2009,2019,2020)$ sadece yüksek lisans çalışmaların yürütülmüş olması dikkat çekmektedir. Bu bağlamda, tez türlerinin yıllar içerisinde dengeli bir şekilde dağılmadığ söylenebilir. Dolayısıyla özellikle doktora düzeyinde daha fazla sayıda çalışmaların yürütülmesi alanyazına önemli katkılar sunacaktır. Çünkü doktora düzeyindeki çalışmaların önemli gerekçeleri arasında insanlığın sahip olduğu bilgi birikimine katkı sunmak yer alır. Elde edilen bulgular dikkate alındığında, matematik eğitimi alanında üstün zekalı ve özel yetenekli bireyler konusunda uzmanlaşmak için yüksek lisans çalışmaların daha fazla olduğu görülmektedir. Bu duruma dikkat çeken Ayvacı ve Bebek (2019), Türkiye'de üstün zekalı ve özel yetenekli bireylere yönelik çalışmaların evrensel bilgiye katkı yapacak düzeyde yoğunlaşmadığının altını çizmektedir. Bu bakımdan bu bireyler hakkında insanlığın bilgi birikimine katkı sunacak doktora düzeyinde çalışmaların artırılması oldukça önemlidir. Araştırmanın bir diğer bulgusu ise lisansüstü tezlerin yaklaşımlarının analizinden elde edilmiştir. Çalışmanın bulgularına göre, lisansüstü tezlerin yarısından fazlasında nicel araştırma yönteminden yararlanıldığı belirlenmiştir. Nitekim lisansüstü tezlerdeki veri toplama araçları analiz edildiğinde ölçek ve test kategorilerinde yer alan ölçme araçlarının daha fazla kullanıldığı belirlenmiştir. Bu çalışmaların çoğunluğunda da nicel yaklaşımların ağırlıkta olduğu gözlemlenmiştir. Dolayısıyla ölçme araçlarının yardımıyla birtakım değişkenler açısından üstün zekalı ve özel yetenekli bireylerin ele alınması araştırmacıların nicel yaklaşımı daha fazla tercih etmelerine neden olduğu düşünülmektedir. Başka bir ifadeyle matematik eğitiminde üstün zekalı ve yetenekli öğrencileri konu edinen çalı̧̧maların konu alanları araştırmacıların nicel yaklaşımlara yönelmesine sebep olmaktadır. Bu bakımdan çalışmaların amaçlarının ve konu alanlarının çeşitliliğinin artması çalışmalarda farklı yaklaşımlara yer verilmesini sağlayacaktır. Özellikle karma yönteminin tezlerde daha az kullanılmış olması bu tür çalışmaların yaklaşımlar açısından farklılaşması gerektiğine işaret etmektedir. Nitekim 
karma araştırma yöntemi araştırmacılara farklı yöntem, strateji ve yaklaşım kullanma olanağı sunarak çoklu veri elde etmelerine yardımcı olmaktadır (Johnson \& Turner, 2003). Aynı zamanda bu araştırma yöntemi araştırmacıların elde ettikleri verilerin zenginliğini, güvenirliğini ve genellenebilirliğini sağlamalarında faydalı olabilir. Bu yüzden tezlerde nicel ve nitel yaklaşımları bünyesinde barındıran ve çeşitli desenlere sahip olan karma araştırma yöntemine ağırlık verilmesinin yararlı olacağı düşünülmektedir. Çünkü lisansüstü tezlerdeki çalışmalarda nicel araştırma yöntemi içeresinden deneysel, tarama ve betimsel desenlerin daha çok kullanıldığının belirlenmiş olmasından da anlaşılacağı üzere araştırmacıların yaklaşım tercihleri yaklaşıma uygun araştırma deseni tercihlerini de etkilemektedir. Bu yüzden bu alanda çalışacak araştırmacıların araştırma konusu ve amacını iyi bir şekilde organize etmesinin çalışmalarına daha fazla derinlik katacağı düşünülmektedir. Nitekim alanyazın incelendiğinde üstün zekalı ve özel yetenekli bireylere yönelik yürütülen çalışmaların çoğunluğunda nicel yaklaşımların daha fazla kullanıldığı belirlenmiştir (Ayvacı \& Bebek, 2019; Dönmez \& İdin, 2017; Nacar, 2015; Özenç \& Özenç, 2013). Elde edilen bulgular, alanyazındaki çalışma bulguları ile paralellik göstermektedir.

Araştırmadan elde edilen bir diğer bulgu ise örneklem düzeyinin belirlenmesine yönelik yapılan analizden elden edilmiştir. Buna göre, lisansüstü tezlerin çoğunluğunun öğrencilerle yürütüldüğü belirlenmiştir. Özellikle ortaokul öğrencilerine bu çalışmalarda sıklıkla yer verilmiştir. En fazla çalışma ortaokul öğrencilerle gerçekleştirilirken en az çalışma ilkokul ve okul öncesi öğrenciler ile yapılmıştır. Tezlerde örneklem düzeyi olarak veliler, yöneticiler ile ilgili dokümanların incelemesine yönelik daha az sayıda çalışmalar yürütülmüştür. Bu bakımdan bu alanda çalışılacak araştırmacıların çalışmalarında olabildiğince tüm paydaşlara yer vermesinin alanyazına daha fazla katkı sunacağı düşünülmektedir. Nitekim üstün zekalı ve özel yetenekli bireylerin genel özellikleri dikkate alındığında birçok faktörün öğrenmeleri üzerinde önemli etkileri olduğu bilinmektedir (Brulles vd., 2010; Gagne, 2004; NAGC, 2008; Renzulli, 2012; Sak, 2014; Sternberg, 1997; VanTassel-Baska, 1997; Winner, 1996). Aynı zamanda elde edilen bu bulgu alanyazında üstün zekalı ve yetenekli öğrenciler üzerinde yürütülen benzer çalışma sonuçlarıyla da örtüşmektedir (Ayvacı \& Bebek, 2019; Dönmez \& İdin, 2017). Diğer yandan lisansüstü tezlerin veri analiz açıklamaları analiz edildiğinde, nicel betimsel ve nicel kestirimsel analizlerinden daha fazla yararlanıldığı belirlenmiştir. Buna göre, ortalama, standart sapma, t-testi, korelasyon, non-parametrik ve varyans analiz teknikleri daha sıklıkla kullanılmıştır. Nitel analiz içerisinde ise içerik ile betimsel analizler daha fazla kullanılmıştır. Bu bağlamda, farklı analiz modellerine olanak tanıyan araştırmalara da yönelmesi ve çalışma kurgusunun bu yönde şekillendirilmesinin önemli olduğunu vurgulamak gerekmektedir. Tüm bu anlatımların yanı sıra çalışmanın belirli bir sınırlılı̆̆ da bulunmaktadır. Çalışmanın en önemli sınırlılığı veri toplama sürecinin Kasım 2020 tarihi ile sınırlandırılmış olmasıdır. Bu tarihten sonra Ulusal Tez Merkezi veri tabanına yüklenen tezlerin içeriklerinde farklılıklar olabilir. Dolayısıyla bu alanda yürütülen çalışmaların yıllar içerisindeki eğilimlerinin ve değişimlerinin daha iyi gözlemlenebilmesi adına benzer çalışmaların yürütülmesinde yarar vardır.

\section{Araştırma ve Yayın Etiği Beyanı}

Yazar, çalışmanın literatür taraması olduğunu bu nedenle etik kurul iznine gerek duyulmadığını beyan etmiş̧tir. 


\section{Kaynakça}

Akay, M. (2018). Üstün yetenekli öğrencilerin eğitiminde kullanılabilecek matematik temelli STEM etkinliklerinin geliştirilmesi (Tez No. 525287) [Yüksek lisans tezi, Atatürk Üniversitesi]. YÖK Tez Merkezi. https://tez.yok.gov.tr/UlusalTezMerkezi/giris.jsp

Akkaş, E. (2014). Farklllaştırılmı̧̧ problem çözme öğretiminin üstün zekalı ve yetenekli öğrencilerin matematik problemlerini çözmelerine, tutumlarına ve yaratıcı düşünmelerine etkileri (Tez No. 357727) [Doktora tezi, Abant İzzet Baysal Üniversitesi]. YÖK Tez Merkezi. https://tez.yok.gov.tr/UlusalTezMerkezi/giris.jsp

Altıntaş, E. (2009). Purdue modeline dayal matematik etkinliği ile öğretimin üstün yetenekli öğrencilerin başarılarına ve eleştirel düşünme becerilerine etkisi (Tez No. 231838) [Yüksek lisans tezi, Marmara Üniversitesi]. YÖK Tez Merkezi. https://tez.yok.gov.tr/UlusalTezMerkezi/giris.jsp

Altıntaş, E. (2014). Üstün zekalı öğrenciler için yeni bir farklılaştırma yaklaşımının geliştirilmesi ve matematik öğretiminde uygulanması (Tez No. 372284) [Doktora tezi, Marmara Üniversitesi]. YÖK Tez Merkezi. https://tez.yok.gov.tr/UlusalTezMerkezi/giris.jsp

Ataman, A. (2004). Üstün zekâlı ve üstün özel yetenekli çocuklar. İçinde M. R. Şirin., A. Kulaksızoğlu., \& A. E. Bilgili (Eds.), Türkiye üstün yetenekli çocuklar kongresi seçilmiş makaleler kitabı (ss.155-168). Çocuk Vakfı Yayınları.

Aygün, Y. İ. (2019). Üstün yetenekli tanısı konulmuş ve tanı konulmamış öğrencilerin farklı ortamlarda matematiksel düşünme süreçlerinin incelenmesi (Tez No.626456) [Yüksek lisans tezi, Amasya Üniversitesi]. YÖK Tez Merkezi. https://tez.yok.gov.tr/UlusalTezMerkezi/giris.jsp

Ayvacı, H. Ş., \& Bebek, G. (2019). Türkiye' de üstün zekâlılar ve özel yetenekliler konusunda yürütülmüş tezlerin tematik incelenmesine yönelik bir çalışma. Pamukkale Üniversitesi Eğitim Fakültesi Dergisi, 45, 267-292. http://dx.doi.org/10.9779/PUJE.2018.233

Bapoğlu-Dümenci, S. S. (2018). Üstün zekalı ve yetenekli çocukların akran ilişkilerine sosyal beceri eğitim programmmn etkisinin incelenmesi (Tez No. 505352) [Doktora tezi, Ankara Üniversitesi]. YÖK Tez Merkezi. https://tez.yok.gov.tr/UlusalTezMerkezi/giris.jsp

Battal-Karaduman, G. (2012). İlköğretim 5. sını üstün yetenekli öğrenciler için farklılaştıılmış geometri öğretiminin yaratıcı düşünme, uzamsal yetenek düzeyi ve erişiye etkisi (Tez No. 351574) [Doktora tezi, İstanbul Üniversitesi]. YÖK Tez Merkezi. https://tez.yok.gov.tr/UlusalTezMerkezi/giris.jsp

Boran, M. (2016). Üstün zekalı ve yetenekli ö̆grencilerin algılanan problem çözme becerilerinin üstbilişsel farkındalıkları ve eleştirel düşünme eğilimleri açısından incelenmesi (Tez No. 439274) [Yüksek lisans tezi, Mersin Üniversitesi]. YÖK Tez Merkezi. https://tez.yok.gov.tr/UlusalTezMerkezi/giris.jsp

Brulles, D., Saunders, R., \& Cohn, S. J. (2010). Improving performance for gifted students in a cluster grouping model. Journal for the Education of the Gifted, 34(2), 327-350. https://files.eric.ed.gov/fulltext/EJ910197.pdf

Budak, İ. (2007). Matematikte üstün yetenekli öğrencileri belirlemede bir model (Tez No. 200003) [Doktora tezi, Karadeniz Teknik Üniversitesi]. YÖK Tez Merkezi. https://tez.yok.gov.tr/UlusalTezMerkezi/giris.jsp

Cohen, L., Manion, L., \& Morrison, K. (2007). Research methods in education (6th Ed.). Routledge/Taylor \& Francis Group. 
Common Core State Standards Initiative (CCSSI) (2010). Common core state standards for mathematics. Washington, DC: National Governors Association Center for Best Practices and The Council of Chief State School Officers. http://www.corestandards.org/Math/

Çalık, T., \& Sezgin, F. (2005). Küreselleşme, bilgi toplumu ve eğitim. Kastamonu Ĕ̆itim Dergisi, 13(1), 5566.

Çalık, M., \& Sözbilir, M. (2014). İçerik analizinin parametreleri. Eğitim ve Bilim, 39(174), 33-38. http://dx.doi.org/10.15390/EB.2014.3412

Dağlıŏlu, H. E. (2002). Anaokuluna devam eden beş-altı yaş grubu çocuklar arasından matematik alanında üstün yetenekli olanlarm belirlenmesi (Tez No. 118239) [Doktora tezi, Hacettepe Üniversitesi]. YÖK Tez Merkezi. https://tez.yok.gov.tr/UlusalTezMerkezi/giris.jsp

Davaslıgil, Ü. (1995). Üstün çocuklar ve eğitimleri. Yaşadıkça Ĕ̆itim, 43, 21-27.

Deringöl, Y., \& Davaslıgil, Ü. (2019). Farklılaştırılmış matematik programının üstün zekalı ve yetenekli öğrencilerin akademik benliklerine etkisi. Milli Ĕ̆itim Dergisi, 48(223), 159-177.

Dinamit, D. (2020). Üstün yetenekli öğrencilerin matematiksel ispat yapma süreçlerinin incelenmesi (Tez No. 636332) [Yüksek lisans tezi, Aydın Adnan Menderes Üniversitesi]. YÖK Tez Merkezi. https://tez.yok.gov.tr/UlusalTezMerkezi/giris.jsp

Dönmez, İ., \& İdin, Ş. (2017). Türkiye'de fen bilimleri eğitimi alanında üstün yetenekli öğrencilerin eğitimi ile ilgili araştırmaların incelenmesi. Üstün Zekâlılar Eğitimi ve Yaratıcılık Dergisi, 4(2), 5774.

Durmaz, B. (2014). Üstün yetenekli ilköğretim öğrencilerinin problem çözme stratejilerini öğrenme düzeyleri (Tez No. 382053) [Doktora tezi, Uludağ Üniversitesi]. YÖK Tez Merkezi. https://tez.yok.gov.tr/UlusalTezMerkezi/giris.jsp

Ergut, G. (2019). Felsefi sorgulama ile birleştirilmiş matematik etkinliklerinin üstün yetenekli öğrencilerin soru sorma becerilerine etkisi (Tez No. 608969) [Yüksek lisans tezi, Dokuz Eylül Üniversitesi]. YÖK Tez Merkezi. https://tez.yok.gov.tr/UlusalTezMerkezi/giris.jsp

European Commission/ EACEA/Eurydice. (2018). Avrupa'da öğretmenlik kariyeri: Erişim, devamlllı ve destek. Eurydice report. Luxembourg: Publication Office of the European Union. https://op.europa.eu/en/home

Flynn, J. R. (2007). What Is Intelligence? Beyond the Flynn Effect. Cambridge University Press.

Gagne, F. (2004). Transforming gifts into talents: The DGMT as a developmental theory1. High Ability Studies, 15(2), 119-147. https://doi.org/10.1080/1359813042000314682

Garlick, D. (2002). Understanding the nature of the general factor of intelligence: The role of individual differences in neural plasticity as an explanatory mechanism. Psychological Review, 109(1), 116136. https://doi.org/10.1037/0033-295X.109.1.116

Genç, M. A. (2016). Üstün yetenekli bireylere yönelik eğitim uygulamaları. Üstün Zekalılar Eğitimi ve Yaratıcılık Dergisi, 3(3), 49-66.

Goleman, D. (2005). Introduction to the tenth anniversary edition. In Emotional intelligence. Bantam Books.

Güçin, G., \& Oruç, Ş. (2015). Türkiye'de üstün yetenekliler ve üstün zekâlılar alanında yapılmış akademik çalışmaların çeşitli değişkenler açısından değerlendirilmesi. Adıyaman Üniversitesi Ĕ̆itim Bilimleri Dergisi, 5(2), 113-135. https://doi.org/10.17984/adyuebd.05095 
Gürel, R. (2011). Illköğretim ikinci kademede okuyan üstün yetenekli olan ve olmayan öğrencilerin matematik kaygı düzeyleri ve bunları kaynakları (Tez No. 288280) [Yüksek lisans tezi, Hacettepe Üniversitesi]. YÖK Tez Merkezi. https://tez.yok.gov.tr/UlusalTezMerkezi/giris.jsp

Hızlı, E. (2013). Üstün zekalı ve yetenekli çocukların matematik tutumlarının çeşitli değişkenler açısından incelenmesi (Tez No. 328582) [Yüksek lisans tezi, İstanbul Üniversitesi]. YÖK Tez Merkezi. https://tez.yok.gov.tr/UlusalTezMerkezi/giris.jsp

İnanır, Ş. N. (2019). Üstün yetenekli öğrencilerin orantısal akıl yürütme becerilerinin incelenmesi (Tez No. 582917) [Yüksek lisans tezi, Necmettin Erbakan Üniversitesi]. YÖK Tez Merkezi. https://tez.yok.gov.tr/UlusalTezMerkezi/giris.jsp

Johnson, B., \&Turner, L. A. (2003). Data collection strategies in mixed methods research. In A. Tashakkori, \& C. Teddie (Eds.), Handbook of mixed methods in social and behavioral research (pp. 297-319). Sage Publishing.

Karataş, Y. D. (2013). Farklılaştırılmış matematik öğretiminin üstün zekalı ve yetenekli öğrencilerde erişiye, yaratıcllı̆̆a, tutuma ve akademik benliğe etkisi (Tez No. 370186) [Doktora tezi, İstanbul Üniversitesi]. YÖK Tez Merkezi. https://tez.yok.gov.tr/UlusalTezMerkezi/giris.jsp

Kieran, C. (1992). The learning and teaching of school algebra. In D. A. Grouws (Ed.), Handbook of research on mathematics teaching and learning: A project of the National Council of Teachers of Mathematics (pp. 390-419). Macmillan Publishing.

Koçak, S. S. (2020). Üstün yetenekli çocukların sosyal duygusal gelişimlerine yönelik geliştirilen psiko-eğitim programını etkisi (Tez No. 620180) [Doktora tezi, Gazi Üniversitesi]. YÖK Tez Merkezi. https://tez.yok.gov.tr/UlusalTezMerkezi/giris.jsp

Kök, B. (2012). Üstün zekalı ve yetenekli öğrencilerde farklılaştırılmış geometri öğretiminin yaratıchlğa, uzamsal yeteneğe ve başarıya etkisi (Tez No. 314714) [Doktora tezi, İstanbul Üniversitesi]. YÖK Tez Merkezi. https://tez.yok.gov.tr/UlusalTezMerkezi/giris.jsp

Krippendorff, K. (2013). Content analysis. An introduction to its methodology (3rd Ed.). Sage Publishing.

Kulaksızoğlu, A. (2004). Üstün yetenekli çocuklar kongresi önsözü. İçinde M. R. Şirin., A. Kulaksızoğlu., \&

A. E. Bilgili (Eds.), I. Türkiye üstün yetenekli çocuklar kongresi üstün yetenekli çocuklar bildiriler kitabı (ss. 7-8). Çocuk Vakfı Yayınları.

Marland, S. P., Jr. (1972). Education of the gifted and talented: Vol. 1. Report to the Congress of the United States by the U. S. Commissioner of Education. Office of Education. https://eric.ed.gov/?id=ED056243

Metin, N. (1999). Üstün yetenekli çocuklar. Öz-Aşama Matbaacilık.

Miles, M. B., \& Huberman, A. M. (1994). Qualitative data analysis: An expanded sourcebook (2nd Ed.). Sage Publishing.

Milli Eğitim Bakanlığı (MEB) (1991). Birinci özel eğitim konseyi. Raporlar-Görüşmeler. MEB Yayınları.

Milli Eğitim Bakanlığı Bilim ve Sanat Merkezleri Yönergesi (2016). Tebliğler Dergisi, Kasım 2016 79/2710. http://tebligler.meb.gov.tr/

Milli Eğitim Bakanlığı (MEB) (2017). Müfredatta yenileme ve değişiklik çalışmalarımız üzerine. Talim Terbiye Kurulu Başkanlığı. http://ttkb.meb.gov.tr

Milli Eğitim Bakanlığı (MEB) (2019). Dünya eğitimine yön verenler I. (M. Safran, B. Ata, H. Köksal, T. Öztürk, Çev.). MEB Destek Hizmetleri Genel Müdürlüğü. https://oygm.meb.gov.tr 
Nacar, S. (2015). 2005-2014 yılları arasında üstün yeteneklilerin matematik eğitimi üzerine yapılan çalışmalar (Tez No. 426399) [Yüksek lisans tezi, İnönü Üniversitesi]. YÖK Tez Merkezi. https://tez.yok.gov.tr/UlusalTezMerkezi/giris.jsp

National Association for Gifted Children (NAGC). (2008). Science, technology, engineering, and mathematics: Our nation's renewable resources. http://www.nagc.org

National Council of Teachers of Mathematics (NCTM) (2014). Principles to actions: Ensuring mathematical success for all. Reston, VA: NCTM. https://www.nctm.org

National Research Council (NRC) (2011). Assessing 21st century skills: Summary of a workshop. National Academies Press. https://doi.org/10.17226/13215

Organisation for Economic Co-operation and Developmen (OECD). (2018). The future of education and skills: Education 2030. http://www.oecd.org/education/

Önal, N. T., \& Büyük, U. (2020). Üstün zekalı olmak. Milli Eğgitim Dergisi, 49(228), 153-174. https://doi.org/10.37669/milliegitim.701743

Özçelik, T. (2017). Üstün yetenekli öğrencilere yönelik geliştirilen farklllaştırllmış matematik dersi öğretim programının etkililiği (Tez No. 484072) [Doktora tezi, Hacettepe Üniversitesi]. YÖK Tez Merkezi. https://tez.yok.gov.tr/UlusalTezMerkezi/giris.jsp

Özenç, M., \& Özenç, E. (2013). Türkiye'de üstün yetenekli öğrencilerle ilgili yapılan lisansüstü eğitim tezlerinin çok boyutlu olarak incelenmesi. Türkiye Sosyal Araştırmalar Dergisi, 171, 13-28.

Özkan, H. H. (2009). Bilgi toplumu eğitim programları. Süleyman Demirel Üniversitesi Sosyal Bilimler Enstitüsü Dergisi, 10(2), 113-132.

Özyaprak, M., \& Davaslıgil, Ü. (2015). Üstün zekalı ve yetenekliler için farklılaştırılmış matematik programının matematik tutumuna etkisi. Üstün Yetenekliler Ĕ̆itimi Araştırmaları Dergisi, 3(2), 26-47.

Özyaprak, M. (2016). Üstün zekâlı ve yetenekli öğrenciler için matematik müfredatının farklılaştırılması. Hasan Ali Yücel Ĕ̆itim Fakültesi Dergisi, 13(2), 115-128.

Reis, S, M., \& Renzulli, J. S. (2003). Research related to the schoolwide enrichment triad model. Gifted Education International, 18(1), 15-39. https://doi.org/10.1177/026142940301800104

Reis, S. M., \& Renzulli, J. S. (2010). Is there still a need for gifted education? An examination of current $\begin{array}{llll}\text { research. Learning and Individual Differences, 20(4), 308-317. } & \text {, }\end{array}$ https://doi.org/10.1016/j.lindif.2009.10.012

Renzulli, J. S. (1978). What makes giftedness? Reexamining a definition. Phi Delta Kappan, 60(3), 180-184. https://doi.org/10.1177/003172171109200821

Renzulli, J. S. (2012). Reexamining the role of gifted education and talent development fort he 21st century: A four-part theoritical approach. Gifted Child Quarterly, 56(3), 150-159. https://doi.org/10.1177/0016986212444901

Sak, U. (2011). Üstün yetenekliler eğitim programları modeli (üyep) ve sosyal geçerliği. Eğitim ve Bilim, $36(161), 213-229$.

Sak, U. (2014). Üstün zekahlar: özellikleri, tanılanmalarl, eğitimleri. Vize Yayınc1lı.

Sandelowski, M., \& Barroso, J. (2007). Handbook for synthesizing qualitative research. Springer Publishing. Saracel, N., \& Aksoy, I. (2020). Toplum 5.0: Süper akıllı toplum. Social Sciences Research Journal, 9(2), 2634. 
Selçuk, Z., Palancı, M., Kandemir, M., \& Dündar, H. (2014). Eğitim ve bilim dergisinde yayınlanan araştırmaların eğilimleri: İçerik analizi. Eğ̀itim ve Bilim, 39(173), 430-453.

Sousa, D. A. (Ed.). (2007). How the special needs brain learns (2nd Ed.). [Kindle Version]. Corwin Press. https://books.google.com.tr

Sözbilir, M., Kutu, H., \& Yaşar, M. D. (2012). Science education research in Turkey: A content analysis of selected features of papers published. In J. Dillon\& D. Jorde (Eds.), The World of Science Education: Handbook of Research in Europe (pp.341-374). Sense Publishers.

Sternberg, R. J. (1997). The concept of intelligence and its role in lifelong learning and success. American Psychologist, 52(10), 1030-1037. https://doi.org/10.1037/0003-066X.52.10.1030

Stenberg, R. J. (2000). Giftedness as developing expertise. In K. A. Heler, F. J. Mönks, R. J. Strenberg, \& R. F. Subotnik (Eds.), International handbook of giftedness and talent, (pp. 55-66). Elsevier.

Taş, N. (2018). Farklllaştırılmış bilgisayar destekli matematik etkinliklerinin üstün yeteneklilerin bilgi işlemsel düşünme öz-yeterlikleri ve matematiğe yönelik tutuma etkisi (Tez No.512614) [Doktora tezi, Atatürk Üniversitesi]. YÖK Tez Merkezi. https://tez.yok.gov.tr/UlusalTezMerkezi/giris.jsp

Taşkın, D. (2016). Üstün yetenekli tanısı konulmuş ve konulmamış öğrencilerin matematikte yaratıcllklarının incelenmesi: Bir özel durum çalışması (Tez No. 448308) [Doktora tezi, Karadeniz Teknik Üniversitesi]. YÖK Tez Merkezi. https://tez.yok.gov.tr/UlusalTezMerkezi/giris.jsp

Türk, T. (2018). Ortaokul matematik dersi öğretim programının üstün yetenekli öğrencilerin eğitimi açısından öğretmen ve öğrenci görüşlerine göre değerlendirilmesi (Tez No. 537637) [Yüksek lisans tezi, Gazi Üniversitesi]. YÖK Tez Merkezi. https://tez.yok.gov.tr/UlusalTezMerkezi/giris.jsp

URL-1: https://tez.yok.gov.tr/UlusalTezMerkezi/giris.jsp

VanTassel-Baska, J. (1997). What matters in curriculum for gifted learners: Reflections on theory, research, and practice. In N. Colangelo \& G. A. Davis (Eds.), Handbook of gifted education (pp. 126-135). Allyn and Bacon.

Winner, E. (1996). Gifted children: Myths and realities. Basic Books.

Yıldırım, A., \& Şimşek, H. (2018). Sosyal bilimlerde nitel araştırma yöntemleri (11. Baskı). Seçkin Yayıncllık.

Yılmaz, K. (2019). Üstün yetenekli öğrencilerin matematiksel düşünme becerilerine göre problem kurma süreçlerinin incelenmesi (Tez No. 569372) [Yüksek lisans tezi, Kırşehir Ahi Evran Üniversitesi]. YÖK Tez Merkezi. https://tez.yok.gov.tr/UlusalTezMerkezi/giris.jsp

\section{EXTENDED SUMMARY}

\section{Introduction}

It is an undeniable fact that gifted/talented individuals have high hopes in shaping the future of countries. Therefore, these individuals are an important value and treasure for their society. Because scientific and economic activities, informatics and information systems, technological advances, artistic works, and many other fields develop thanks to their driving force. Especially in the last thirty years, with the increase in the need for qualified manpower, efforts to provide talented students with more qualified education have gained momentum in many countries (Önal \& Büyük, 2020). The fact that the futures of nations are closely related to the improving capabilities of the individuals they have has added more momentum to this process (MoNE, 2019). When the studies conducted on gifted/talented students in the field of mathematics education in our country are examined in general, it is seen that teaching practices are predominant as well as the studies on identifying these students (Akay, 2018; Altıntaş, 2014; Battal-Karaduman, 2012; Budak, 2007; Dağlıŏlu, 2002; Karataş, 2013; Kök, 2012; Özçelik, 
2017; Özyaprak, 2016; Özyaprak \& Davaslıgil, 2015; Taş, 2018). In Turkey, the increasing number of postgraduate theses studies on gifted/talented students in mathematics education and the presence of a limited number of studies in the literature examining the content of these theses emphasize the importance of research. Also, the continuity of such studies in terms of determining what the changes of studies carried out in this field have been over the years and how they have shown a trend reveals the necessity of the study. In this context, the study aims to examine the postgraduate theses on gifted and talented students in mathematics education in Turkey from both thematic and methodological points of view.

\section{Method}

Within the scope of this research, postgraduate theses conducted until November 2020 on gifted/talented students in the field of mathematics education were considered systemically from a thematic and methodological point of view. In this way, it was tried to determine the trends of the studies carried out in this field. In the study which was considered based on a qualitative understanding the postgraduate theses were examined and described by document analysis.

\section{Findings}

According to the findings, it was determined that postgraduate theses were combined under four different themes. These themes are in the form of studies to identify gifted/talented students, educational activities carried out for gifted/talented students, studies to address gifted/talented students in the context of different variables, and evaluation studies centered on gifted/talented students. In the thesis studies, most of the studies on the cognitive features of gifted students (38) were investigated. These studies are followed by studies that focus on effective characteristics (12) and success levels (11) of gifted students. Study subjects of theses; covers seven different learning areas that include numbers and operations/algebra, algebra, geometry and measurement, data processing, probability, and skills to gain problem-solving skills within the scope of the early education program. It was determined that algebraic expressions and identities (11), and equality and equation (10) were mostly discussed in thesis studies. When the distribution of theses was examined, it was determined that there was not a balanced distribution of master's (31) and doctoral (22) studies. When the approaches of the theses were examined, it was determined that they were grouped under three categories: quantitative, qualitative, and mixed methods. $54.54 \%$ of the studies carried out are quantitative, $23.64 \%$ are qualitative and $21.82 \%$ are mixed approaches. Most of the theses have been studied with middle school students (32). When the distribution of theses according to data collection tools was examined, it was determined that the most preferred data collection tool was a semi-structured interview (19). When the distribution of postgraduate theses according to the data explanations was examined, the maximum mean, standard deviation (25), frequency, percentage, and chart (12), and graphic representation (10) were used.

\section{Discussion, Conclusion and Suggestions}

In this study, postgraduate theses on gifted/talented students in mathematics education in Turkey were analyzed both thematic and methodological. When the purpose and sub-problem sentences of the postgraduate theses made for gifted/talented students in mathematics education were analyzed, it was determined that the cognitive features of the students were examined with the help of variables such as problem-solving, reasoning, metacognitive, scientific process, creativity, critical, reflective, critical, procedural and spatial thinking skills. Undoubtedly, one of the main reasons for this situation is to better understand the cognitive features of gifted/talented individuals. But the fact that most studies have focused on this theme limits the study of gifted/talented individuals from a holistic point of view. It is known that it is important to support gifted and talented individuals emotionally (Goleman, 2005). In Turkey, it was determined that a smaller number of studies were carried out on themes covering detection and evaluation studies on gifted students in mathematics education. Accordingly, it was determined that the studies aimed at developing models, tests, and approaches for the teaching of gifted/talented individuals, creating a progressive system, including teacher opinions, 
determining needs and problems, and studying textbooks were not sufficient. One of the remarkable findings of the study is that the number of studies with application content included within the theme of educational activities is not at a sufficient level. This finding also coincides with the statement that practical studies are not done at adequately in our country (Ayvacı \& Bebek, 2019; Koçak, 2020).

Another finding in the analysis of theses is that there is more work in the field of algebra learning. The fact that the field of learning algebra includes an intense mental activity and the doorway to abstract thinking may have led researchers to these issues. Because algebra learning area is defined as a computational tool that symbolizes equation solutions and shows numerical relations and properties (Kieran, 1992). It has been observed that quantitative approaches predominate in most of these studies. In this respect, it is recommended to increase the diversity of the aims and subject areas of the studies. The fact that the mixed method was used less frequently in theses indicates that such studies should differ in terms of approaches. The mixed research method helps researchers to obtain multiple data by providing the opportunity to use different methods, strategies, and approaches (Johnson \& Turner, 2003). When the literature was examined, it was determined that quantitative approaches were used more in the majority of the studies conducted for gifted/talented individuals (Ayvacı \& Bebek, 2019; Dönmez \& İdin, 2017; Özenç \& Özenç, 2013). Especially middle school students are often involved in these studies. Most studies were conducted with middle school students, while the least studies were conducted with primary and pre-school students. In this regard, it is recommended that researchers who will work in this field include as many stakeholders as possible in their work. It is known that many factors have important effects on their learning when considering the general characteristics of gifted and talented individuals (Brulles et al., 2010; Gagne, 2004; NAGC, 2008; Renzulli, 2012; Sak, 2014; Sternberg, 1997; VanTassel-Baska, 1997; Winner, 1996). On the other hand, when the data analysis explanations of postgraduate theses are analyzed, it was determined that quantitative descriptive and quantitative predictive analysis were used more.

Ek-1: Araştırmada İncelenen Lisansüstü Tezlere Ait Bilgiler

\begin{tabular}{|c|c|c|c|}
\hline No & Tez Adı & Yazar & Yil1 \\
\hline 1 & $\begin{array}{l}\text { Anaokuluna devam eden beş-altı yaş grubu çocuklar arasından matematik alanında üstün } \\
\text { yetenekli olanların belirlenmesi }\end{array}$ & Hacer Elif Dağlığlu & 2002 \\
\hline 2 & Matematikte üstün yetenekli öğrencileri belirlemede bir model ${ }^{a}$ & İbrahim Budak & 2007 \\
\hline 3 & $\begin{array}{l}\text { Raven'in ilerleyen matrisler plus testinin } 12-13 \text { yaş çocukları üzerinde geçerlik, güvenirlik ve } \\
\text { ön norm çalışmalarına göre üstün zekalı olan ve olmayan öğrencilerin mantıksal düşünme } \\
\text { yeteneklerinin karşılaştırılması }{ }^{\text {b }}\end{array}$ & n & 2008 \\
\hline 4 & $\begin{array}{l}\text { Raven spm plus testi } 5.5-6.5 \text { yaş geçerlik, güvenirlik ve ön norm çalışmalarına göre üstün zekalı } \\
\text { olan ve olmayan öğrencilerin erken matematik yeteneklerinin karşılaştırılması }{ }^{b}\end{array}$ & Evrim Kurt & 2008 \\
\hline 5 & $\begin{array}{l}\text { Purdue modeline dayalı matematik etkinliği ile öğretimin üstün yetenekli öğrencilerin } \\
\text { başarılarına ve eleștirel düşünme becerilerine etkisi }{ }^{b}\end{array}$ & Esra Altıntaş & 2009 \\
\hline 6 & $\begin{array}{l}\text { Üstün yetenekli ilköğretim ikinci kademe öğrencileri için matematik programına yönelik } \\
\text { ihtiyaç analizi }{ }^{b}\end{array}$ & Berna Aygün & 2010 \\
\hline & $\begin{array}{l}\text { İlköğretimdeki üstün yetenekli öğrencilerin yaratıcı problem çözmeye yönelik erişi } \\
\text { düzeylerinin ve kritik düşünme becerilerinin belirlenmesi }\end{array}$ & Burak Karabey & 2010 \\
\hline 8 & stün yetenekli olan ve olmayan öğrencilerin matematik & Ran & 2011 \\
\hline & $\begin{array}{l}\text { Üstün zekalı ve yetenekli öğrencilerde farklılaştırılmış geometri öğretiminin yaratıcılı̆̆a, } \\
\text { uzamsal yeteneğe ve başarıya etkisia }\end{array}$ & Başak Kök & 2012 \\
\hline & $\begin{array}{l}\text { İlköğretim } 4 \text {. ve } 5 \text {. sınıf fen ve teknoloji dersi ile matematik dersinde üstün zekalı öğrencilere } \\
\text { yönelik uygulamaların değerlendirilmesi }\end{array}$ & Ezlam Susam & 2012 \\
\hline & $\begin{array}{l}\text { Üstün yetenekli ortaöğretim öğrencilerinin matematiksel problem çözme durumlarındaki öz } \\
\text { düzenleme davranışları }{ }^{a}\end{array}$ & Gönül Yazgan Sağ & 2012 \\
\hline & $\begin{array}{l}\text { İlköğretim 5. sınıf üstün yetenekli öğrenciler için farklılaştırılmış geometri öğretiminin yaratıcı } \\
\text { düşünme, uzamsal yetenek düzeyi ve erişiye etkisia }\end{array}$ & $\begin{array}{l}\text { Gülşah Batdal } \\
\text { Karaduman }\end{array}$ & 2012 \\
\hline & $\begin{array}{l}\text { Üstün zekalı ve yetenekli öğrencilere yönelik farklılaştırılmış matematik öğretiminin erişi, } \\
\text { tutum ve yaratıcılığa etkisia }\end{array}$ & Melodi Özyaprak & 2012 \\
\hline & $\begin{array}{l}\text { Üstün zekalı ve yetenekli çocukların matematik tutumlarının çeşitli değişkenler açısından } \\
\text { incelenmesi }{ }^{b}\end{array}$ & Emine Hızlı & 2013 \\
\hline
\end{tabular}


15 Üstün ve normal zekâ düzeyindeki öğrencilerin matematikte öz-düzenleyici öğrenmeleri ve motivasyonel inançları ${ }^{\mathrm{b}}$

16 Sınıf öğretmenlerinin ve ilköğretim matematik öğretmenlerinin matematikte üstün zekalı Sumeyra Tütüncü öğrencilere yönelik algıları ${ }^{\mathrm{b}}$

17 Farklılaştırılmış matematik öğretiminin üstün zekalı ve yetenekli öğrencilerde erişiye, Yasemin D. Karataş 2013 yaratıcılığa, tutuma ve akademik benliğe etkisia

18 Üstün yetenekli öğrencilerin matematik yaratıcılıklarını açıklamaya yönelik bir model Savaş Akgül geliştirilmesia

19 Farklılaştırılmış problem çözme öğretiminin üstün zekalı ve yetenekli öğrencilerin matematik problemlerini çözmelerine, tutumlarına ve yaratıcı düşünmelerine etkileria

20 Matematik alanında üstün yetenekli ve zekalı öğrencilerin bazı değişkenler açısından veri madenciliği ile belirlenmesi ${ }^{b}$

219 . sınıf üstün zekalı öğrencilerin geometri problem çözme stratejileri ve Van Hiele geometri Mustafa Z. Aydoğdu düşünme düzeyleri ile ilişkilendirilmesi ${ }^{b}$

22 Üstün zekalı öğrenciler için yeni bir farklılaştırma yaklaşımının geliştirilmesi ve matematik Esra Altıntaş öğretiminde uygulanmasi ${ }^{a}$

23 Üstün yetenekli ilköğretim öğrencilerinin problem çözme stratejilerini öğrenme düzeyleria

24 Fen ve matematik entegrasyonu ile hazırlanan etkinliklerin üstün yetenekli ortaokul 6. sınıf öğrencilerinin eleştirel düşünme ve bilimsel süreç becerilerine etkisia

25 Matematiği GeoGebra ile öğretmenin limit ve süreklilik konularının kavramsal anlaşılmasına olan etkisi: Üstün zekalı ve yetenekli Türk öğrencileri örneğ ${ }^{b}$

26 Üstün zekalı ve normal zekalı ortaokul öğrencilerinin problem çözme yaklaşımlarının karşılaştırılmalı olarak incelenmesi ${ }^{b}$

27 2005-2014 yılları arasında üstün yeteneklilerin matematik eğitimi üzerine yapılan çalışmalarb

28 Beşinci ve altıncı sınıf matematikte üstün yetenekli öğrencilere yönelik farklılaştırılmış etkinliklerin tasarlanması ve geliştirilmesia

29 Üstün zekalı ve yetenekli öğrencilerin algılanan problem çözme becerilerinin üstbilişsel farkındalıkları ve eleştirel düşünme eğilimleri açısından incelenmesi ${ }^{b}$

30 Üstün yetenekli öğrencilerin BİLSEM ve matematik kavramına ait metaforik algılarının incelenmesi ${ }^{\mathrm{b}}$

31 Proje temelli yaklaşıma dayalı erken müdahale programının üstün yetenekli çocukların problem çözme becerisine etkisia

32 Üstün yetenekli tanısı konulmuş ve konulmamış öğrencilerin matematikte yaratıcılıklarının incelenmesi: Bir özel durum çalışması ${ }^{\mathrm{a}}$

33 Üstün yetenekli öğrencilerin matematiksel yaratıcılıklarının matematiksel modelleme etkinlikleri sürecinde değerlendirilmesia

34 Üstün yetenekli ve normal öğrencilerin matematiksel örüntü başarılarının incelenmesi ${ }^{\text {b }}$

35 Üstün yetenekli öğrencilere yönelik geliştirilen farklılaştırılmış matematik dersi öğretim programının etkililiği ${ }^{a}$

36 Üstün/özel yetenekli öğrencilerin geometri düzeylerinin bazı değişkenler açısından incelenmesi ${ }^{\mathrm{b}}$

37 Üstün yetenekli ortaokul öğrencilerinin uzamsal akıl yürütme becerilerinin astronomi konularına yönelik kavramsal anlayışları ve akademik başarıları ile ilişkisinin incelenmesia

38 Farklılaştırılmış bilgisayar destekli matematik etkinliklerinin üstün yeteneklilerin bilgi işlemsel düşünme öz-yeterlikleri ve matematiğe yönelik tutuma etkisi ${ }^{a}$

39 Matematik öğretmenlerinin üstün yetenekliler eğitimine ilişkin tutum ve öz yeterliklerinin incelenmesi $^{\mathrm{b}}$

40 Üstün yetenekli öğrencilerin matematiksel üretkenlik düzeyleri ile eleştirel düşünme becerileri arasındaki ilişkinin incelenmesi ${ }^{\mathrm{b}}$

41 Üstün yetenekli öğrencilerin eğitiminde kullanılabilecek matematik temelli STEM etkinliklerinin geliştirilmesi ${ }^{b}$

42 Üstün yetenekli ortaokul öğrencilerinin proje tabanlı temel robotik eğitim süreçlerindeki yaratıcı, yansıtıcı düşünme ve problem çözme becerilerine ilişkin davranışlarının ve görüşlerinin incelenmesi ${ }^{\mathrm{b}}$

43 İlkokula devam eden üstün yetenekli çocukların problem çözme becerilerine eğitimin etkisinin incelenmesi ${ }^{a}$

44 Ortaokul matematik dersi öğretim programının üstün yetenekli öğrencilerin eğitimi açısından öğretmen ve öğrenci görüşlerine göre değerlendirilmesi ${ }^{\mathrm{b}}$

45 Üstün zekalı ve normal zekalı ortaokul öğrencilerinin uzamsal düşünme yeteneklerinin karşılaştırılmalı olarak incelenmesi ${ }^{\mathrm{b}}$

46 Üstün yetenekli öğrencilerin matematiksel düşünme becerilerine göre problem kurma süreçlerinin incelenmesi ${ }^{\text {b }}$

47 Üstün yetenekli öğrencilerin orantısal akıl yürütme becerilerinin incelenmesi ${ }^{b}$

48 Matematikte üstün yetenekli Türk öğrencilerin rutin olmayan problem çözme süreçleri ${ }^{b}$

Burcu Durmaz

Ahsen Seda Kılıç

Mustafa Aydos

Nihat Koçyiğit

Sema Nacar

Duygu Özdemir

Murat Boran

İsmail Satmaz

Ahmet Bildiren

Duygu Taşkın

2014

2015

2015

2015

2015

2016

2016

2016

2016

2016

Şeyma Şengil Akar

Şükran Dayan

Tünay Özçelik

Tuğçe M. Sağır

Gürlevik

Pelin Ertekin

Nurullah Taş

Yelda Şişman

2018

2018

Fatime Yavuz Açıl

Mustafa Akay

Biray Kırkan

Rıdvan Karabulut

Tuğba Türk

Dinçkan Harput

Kâmil Yılmaz

Şeyma N. İnanır

Damla Ö. Ünal 
49 Felsefi sorgulama ile birleştirilmiş matematik etkinliklerinin üstün yetenekli öğrencilerin soru

Gülünay Ergut 2019 sorma becerilerine etkisib

50 Üstün yetenekli tanısı konulmuş ve tanı konulmamış öğrencilerin farklı ortamlarda Yavuz İsa Aygün matematiksel düşünme süreçlerinin incelenmesi ${ }^{\mathrm{b}}$

51 Üstün yetenekli öğrencilerin matematik dersine karşı tutum ve özyeterlilik algılarının bazı değişkenler açısından incelenmesi ${ }^{\mathrm{b}}$

52 Matematikte üstün yetenekli ortaokul öğrencilerinin matematik öğretmenlerine ilişkin Yasemin Saka Kılıç algılarının incelenmesi ${ }^{\mathrm{b}}$

53 Üstün yetenekli öğrencilerin matematiksel ispat yapma süreçlerinin incelenmesi ${ }^{\mathrm{b}}$

Duygu Dinamit

Dilek Kocaoğlu

a: Doktora b: Yüksek Lisans 